\title{
Under construction
}

The professional positioning of HR practitioners

Sara Lindström

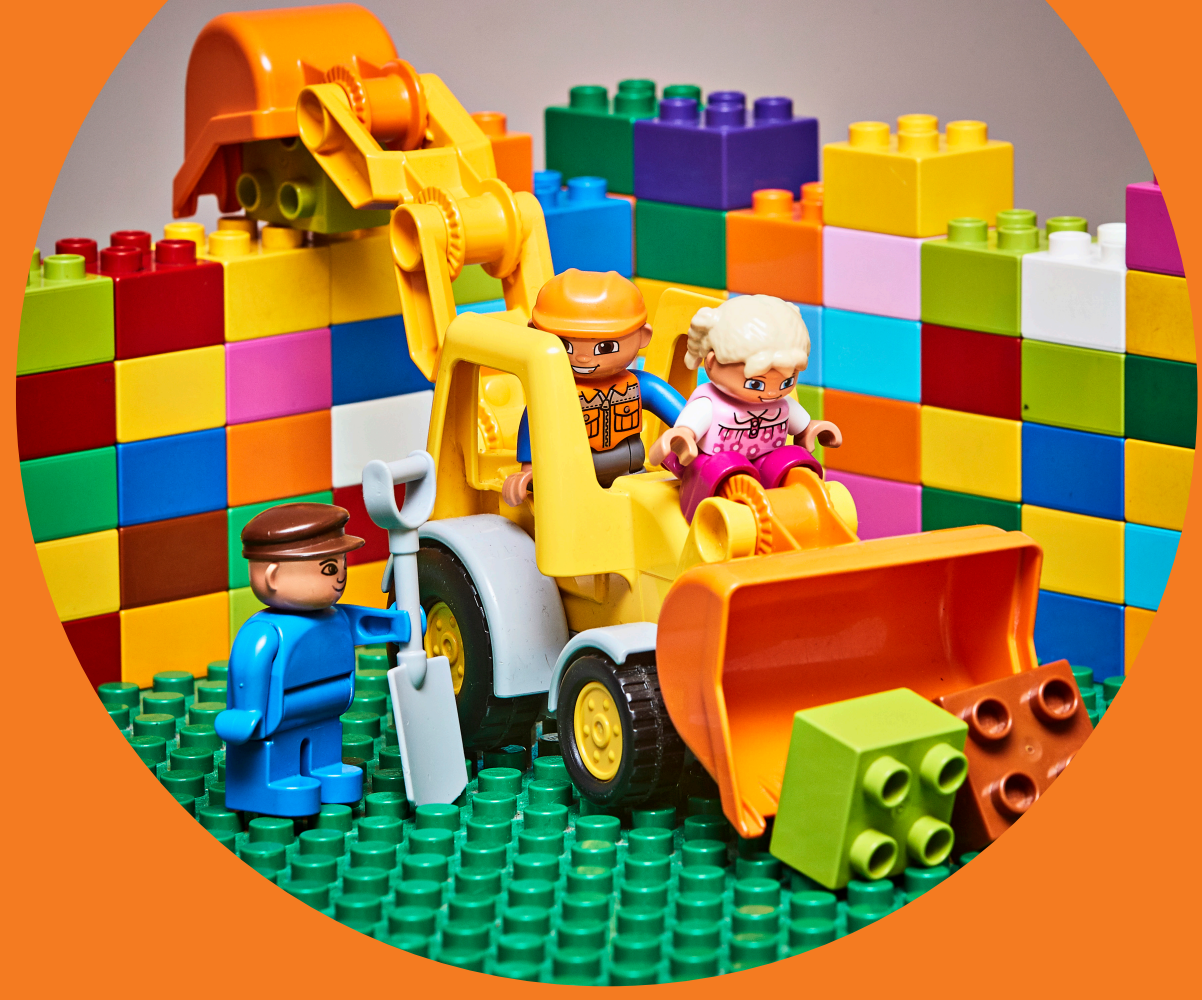




\section{Under construction}

The professional positioning of HR practitioners

\section{Sara Lindström}


Professor Keijo Räsänen, Aalto University School of Business, Finland

Thesis advisor

Doctor Sinikka Vanhala, Aalto University School of Business, Finland

\section{Preliminary examiners}

Professor Anne Keegan, University College Dublin, Ireland

Professor Riitta Viitala, Vaasa University, Finland

\section{Opponent}

Professor Anne Keegan, University College Dublin, Ireland

Aalto University publication series

DOCTORAL DISSERTATIONS 197/2019

(c) 2019 Sara Lindström

ISBN 978-952-60-8784-9 (printed)

ISBN 978-952-60-8785-6 (pdf)

ISSN 1799-4934 (printed)

ISSN 1799-4942 (pdf)

http://urn.fi/URN:ISBN:978-952-60-8785-6

Images: Mikko and Klaus Hannula

Unigrafia Oy

Helsinki 2019

Finland 
Author

Sara Lindström

Name of the doctoral dissertation

Under construction

\begin{tabular}{l}
\hline Publisher School of Business \\
\hline Unit Department of Management Studies \\
\hline Series Aalto University publication series DOCTORAL DISSERTATIONS 197/2019 \\
\hline Field of research Organization \& Management \\
\hline Date of the defence 1 November 2019 \\
$\begin{array}{l}\text { Language English } \\
\square \text { Monograph }\end{array}$ Article dissertation $\square$ Essay dissertation
\end{tabular}

\section{Abstract}

The overall aim of this study is to increase the understanding of how municipal HR practitioners discursively construct professional positions for themselves. This study brings attention to how they relate to both other actors in the municipalities as well as institutionalized discourses of high performance and well-being at work in Finnish work life during the first decade of the 2000 .

Theoretically, I contribute to the literature on HR practitioner roles by emphasizing the discursive, institutional context when exploring HR positioning. Also, I highlight the relational aspect of HR positioning and extend the scope of relevant HR practitioner relations to local policymakers and local residents. Furthermore, I show how well-being at work is deployed as a building block in the positioning of HR practitioners.

Empirically, I ask how HR practitioners use discourses to strengthen their position in municipal organizations. In order to answer this question, I focus on different aspects of discursive positioning by analysing semi-structured interviews with municipal HR practitioners. First, I highlight the relational positioning of HR practitioners towards line managers, top managers and policy makers (Study 1), local residents (Study 2) and employees (Study 2 and 3). Second, I focus on their contextual positioning in relation to the institutionalized discourses of well-being at work (Study 3) and high performance (Studies 1,2 and 3).

By adopting a discursive perspective to HR practitioner positioning, I offer a deep contextual understanding to the phenomenon. As a result, the ambiguous position of HR practitioners turns out to be an asset; it enables HR practitioners to adhere to the different discourses of high performance and well-being at work simultaneously. Still, well-being at work is constructed more as a bridge to performance than a result in itself.

Keywords discourse analysis, HR practitioners, HR work, performance, professional positioning, well-being at work

\begin{tabular}{lc}
\hline ISBN (printed) $978-952-60-8784-9$ & ISBN (pdf) $978-952-60-8785-6$ \\
\hline ISSN (printed) $1799-4934$ & ISSN (pdf) $1799-4942$ \\
\hline Location of publisher Helsinki & Location of printing Helsinki $\quad$ Year 2019 \\
\hline Pages 121 & urn http://urn.fi/URN:ISBN:978-952-60-8785-6 \\
\hline
\end{tabular}



Tekijä

Sara Lindström

Väitöskirjan nimi

Under construction: The professional positioning of HR practitioners

\begin{tabular}{ll}
\hline Julkaisija Kauppakorkeakoulu \\
\hline Yksikkö Johtamisen laitos \\
\hline Sarja Aalto University publication series DOCTORAL DISSERTATIONS & 197/2019 \\
\hline Tutkimusala Organisaatiot ja johtaminen & \\
\hline Väitöspäivä 01.11.2019 & \\
\hline Kieli Englanti & $\square$ Esseeväitöskirja \\
\hline Monografia
\end{tabular}

\section{Tiivistelmä}

Tämän tutkimuksen tavoitteena on lisätä ymmärrystä siitä, miten kunta-alan HR-ammattilaiset (henkilöstöalan ammattilaiset) rakentavat omia ammatillisia asemiaan. Ammatillisilla asemilla tarkoitan heidän itse määrittelemiään asemia, jotka mahdollistavat ja rajoittavat sen mitä he kustakin asemasta käsin voivat tehdä ja sanoa. Tutkimus tuottaa tietoa niistä tavoista, joilla he asemoivat itsensä paitsi muihin kunta-alan toimijoihin myös institutionalisoituneisiin työelämädiskursseihin - vakiintuneisiin kielenkäytön tapoihin - suomalaisessa työelämässä 2000luvun ensimmäisellä vuosikymmenellä. Näitä diskursseja kutsun työhyvinvointi- ja tuloksellisuusdiskursseiksi.

Osallistun HR-ammattilaisten roolien tutkimukseen osoittamalla institutionaalisen kontekstin merkityksen HR-ammattilaisten asemoinnissa. Lisäksi laajennan käsitystä HR-ammattilaisten ja muiden kuntatoimijoiden välisistä suhteista osoittamalla kuntapäättäjät ja asukkaat tärkeinä toimijoina, joiden varaan HR-ammattilaiset rakentavat asemaansa. Lopuksi osoitan miten he käyttävät työhyvinvointia oman ammatillisen asemansa rakennuspalikkana.

Empiirisesti kysyn miten HR-ammattilaiset käyttävät diskursseja vahvistaakseen asemaansa kuntaorganisaatioissa. Vastauksena kysymykseen olen keskittynyt ammatillisen asemoinnin eri osa-alueisiin analysoimalla puolistrukturoituja haastatteluja, jotka on toteutettu HR-

ammattilaisten kanssa. Tulokset osoittavat kaksi vahvaa ammatillisen asemoinnin tapaa. Ensiksi, he asemoivat itsensä suhteessa esimiehiin, ylimpään johtoon, kuntapäättäjiin (Osatutkimus 1), asukkaisiin (Osatutkimus 2) ja kuntatyöntekijöihin (Osatutkimukset 2 ja 3). Toiseksi, keskityn heidän kontekstuaaliseen asemointiinsa suhteessa institutionalisoituneisiin diskursseihin työhyvinvoinnista ja tuloksellisuudesta (Osatutkimukset 1, 2 ja 3).

Diskursiivinen näkökulma mahdollistaa syvän kontekstuaalisen ymmärryksen HR-ammattilaisten asemoinnista. Tutkimus toteaa, että moniselitteinen ja jatkuvan muutoksen kohteena oleva asema on itse asiassa etu HR-ammattilaisille. Moniselitteinen asema mahdollistaa, että he voivat kiinnittyä sekä tuloksellisuus- että työhyvinvointidiskurssiin samanaikaisesti. Kuitenkin työhyvinvointi on aseman rakennuspalikkana alisteinen tuloksellisuudelle.

Avainsanat ammatillinen asemointi, HR-ammattilaisuus, henkilöstötyö, diskurssianalyysi, , tuloksellisuus, työhyvinvointi

\begin{tabular}{|c|c|c|}
\hline ISBN (painettu) 978-952-60 & ISBN (pd & $0-8785-6$ \\
\hline ISSN (painettu) 1799-4934 & ISSN (pd & \\
\hline Julkaisupaikka Helsinki & Painopaikka Helsinki & Vuosi 2019 \\
\hline
\end{tabular}





\section{Acknowledgements}

This work has been supported by many wonderful colleagues, friends and family members. My gratitude goes to all of you.

My foremost thanks are dedicated to my supervisors, Sinikka Vanhala and Keijo Räsänen. Sinikka, you have encouraged me to pursue a career in research since the start. During these years, I have enjoyed your support during the different stages of this journey. As a co-author, you have taught me about the precision in academic writing more than anyone, and you have always believed in my ability to make my own decisions and argue for them. Keijo, I am deeply grateful for your supportive comments during the writing of the introductory essay. Also, your help in making it through the ropes of university procedures in preparing for the defense has been invaluable. It has been an inspiration for me to work with you both.

My closest colleague during these years has been Tiina Taipale. Thank you Tiina for introducing me to Sinikka and the discipline of Organization and Management at Aalto University of Business. You have shared the joys and insecurities in academic work with me when it comes to doing research and teaching. From you I have learned how to continuously develop and challenge myself. Most importantly, you are a friend I can count on.

Another true delight has been the collaboration and collegiality with Lotta Harju and Minna Janhonen at the Finnish Institute of Occupational Health. Lotta, your ambitious and determined take on research has inspired me and helped me greatly to believe in myself. Minna, your positive energy and our wonderful collaboration has helped me see the possibilities and solutions instead of risks and setbacks.

In Latin, agraphia stands for fear of writing. I am fortunate to have been a member of an Agraphia group at Aalto University, dedicated to academic writing. Thank you, fellow writers, for sharing your thoughts and experiences on writing, for making writing social and for reinforcing good writing habits.

I am deeply grateful to my colleagues at the Finnish Institute of Occupational Health who have shared the joys and challenges of combining research with development work. During the past year, I have especially enjoyed the TohtorixMaisterix writing group meetings and lunches. Heli Ansio, Jarno Turunen and Tiina Taipale, thank you for your friendship and for giving me a safe place to share the final stages in preparing this thesis. I also want to thank my former supervisor Krista Pahkin who during the years of working at the Finnish Institute of Occupational Health always encouraged me to finalize this thesis. 
This work has been financially supported by Helsinki School of Economics Support Foundation, the Academy of Finland and the Finnish Work Environment Fund.

My warmest thank you my pre-examiners, Professor Anne Keegan from the University College Dublin and Professor Riitta Viitala from Vaasa University. Thank you for your work in pre-examining this thesis and for your valuable comments. Reading the final statements were milestones for me in completing this work. Anne, I am especially honored to have you as my opponent.

My parents, I specifically want to thank you for always making me feel welcome and for giving me a childhood filled with reading. Bing an avid reader has been a prerequisite for my academic work as well as my well-being. A special thank you is directed to my late grandmother, Famo, for unconditional belief in everything I have pursued.

My partner, Mikko, rakastan sinua. You have made me laugh so many times by making me see the sometimes absurdness of academic conventions. You have made the finalization of this thesis possible, since this introductory essay was written during weekends and holidays when I emigrated to our summer house in Luumäki, my parents in Kotka or to local libraries and coffee shops in Helsinki while you have taken the best care possible of our son, Klaus.

Thank you, my dear Klaus, for being my super hero of imagination and curiosity, and for taking my mind of academic work completely for a year.

Helsinki, 3o September 2019

Sara Lindström 


\section{Contents}

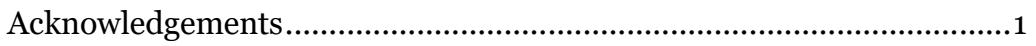

List of Publications …........................................................................... 5

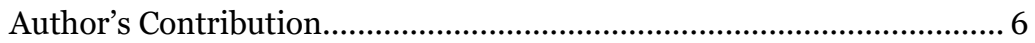

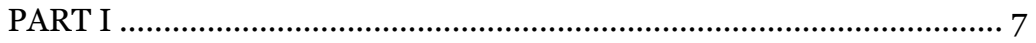

1. Introduction....................................................................... 9

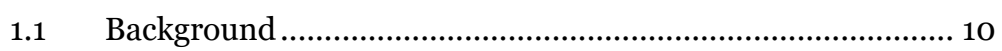

1.2 Research focus ...............................................................13

1.3 Aim of the study ................................................................. 15

1.4 Structure of the thesis .........................................................16

2. Studying professional positions …..............................................17

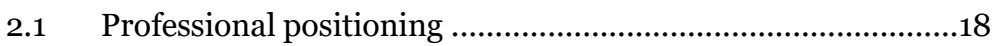

2.1.1 Understanding professional positioning as an active process ...................................................................19

2.2 The shaky position of HR practitioners ..................................21

2.2.1 HR practitioners, high performance and well-being at work ........................................................... 24

3. Institutionalized working life discourses in the Finnish municipal context................................................................. 27

3.1 Municipal organizations as a research context..................... 27

3.2 High performance and well-being at work as institutional discourses in Finnish working life ........................................ 29

3.2.1 The discourse of high performance strengthens................. 29

3.2.2 The discourse of well-being at work enters the picture .......30

4. Methodology ............................................................................. 33

4.1 Moderate social constructionism........................................... 33

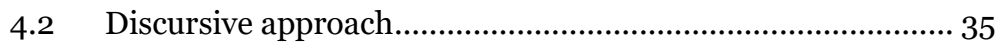

4.3 Collecting empirical materials ................................................ 36

4.4 Doing analysis ................................................................... 38

4.5 Positioning myself as a researcher....................................... 40 
5. Three studies on the professional positioning of

HR practitioners in municipal organizations.

5.1 Divergence in HR functional roles in local government

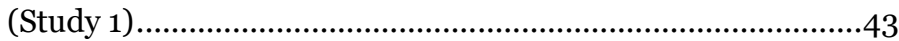

5.2 Performance in local government HRM: The role of external customers (Study 2)..................................................44

5.3 Legitimating the professional position of HR through well-being at work (Study 3) ..................................................46

6. Discussion and conclusions .......................................................49

6.1 Key contributions ................................................................ 50

6.1.1 Contributions to the literature on HR roles....................... 50

6.1.2 Contributions to the literature on professional positioning 52

$6.2 \quad$ Practical implications ...........................................................5 53

6.2.1 HR practitioner implications .............................................54

6.2.2 Policy implications............................................................54

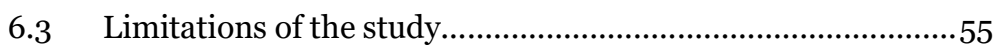

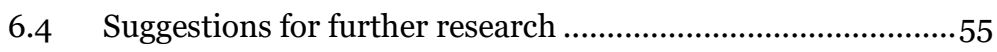

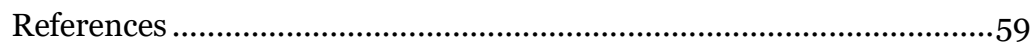

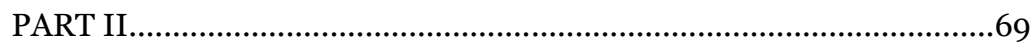




\section{List of Publications}

This doctoral thesis consists of an introductory essay and of the following publications.

1. Lindström, S. \& Vanhala, S. (2011). Divergence in HR functional roles in local government. Public Management Review, 13(7), 1023-1040. DOI: 10.1080/14719037.2011.589620

2. Lindström, S. \& Vanhala, S. (2013). Performance in local government HRM: The role of external customers. Baltic Journal of Management, 8(3), 252-268. DOI: 10.1108/BJOM-10-2012-0094

3. Lindström, S. (2016). 'An army of our own'. Legitimating the professional position of HR through well-being at work. Scandinavian Journal of Management, 32(4), 189-196. DOI: 10.1016/j.scaman.2016.08.003 


\section{Author's Contribution}

Publication 1: Divergence in HR functional roles in local government

Sara Lindström was the lead author of this essay. She was responsible for the literature review and theoretical framework. She also designed the research focus and framing together with the second author, took care of the procedure of the analysis, and authored the discussion of results in light of previous research.

Sinikka Vanhala, the second author, brought her expertise in prior literature. She revised the theoretical framing and contributed to the positioning of the results in the relevant literature. Moreover, she provided her insights into the discussion of results.

Publication 2: Performance in local government HRM: The role of external customers

Sara Lindström was the lead author of this essay. The research idea was developed by her, and she was responsible for the literature review and theoretical framework. She also designed the research focus and framing, was responsible for the data collection, the process of analysis, and authored the discussion of results in light of data.

Sinikka Vanhala, the second author, revised the theoretical framing and contributed to the positioning of the results within the existing research as well as the quality of the research. She provided her insights into the discussion of results.

Publication 3: 'An army of our own'. Legitimating the professional position of HR through well-being at work

Single authored by Sara Lindström 
PART I 



\section{Introduction}

The professional position of HR (Human Resource) practitioners - a standpoint from which they speak and act - is a recurrent topic of debate in academic research and among HR practitioners themselves (Alfes et al. 2010; Arrowsmith \& Parker 2013; Farndale \& Hope-Hailey 2009; Keegan \& Francis 2010; Legge 2005; Pohler \& Willness 2014; Wright 2008). So far, the dominant perspective among researchers has been that the key to improving the position of HR practitioners would be to adopt the role of a business partner contributing to organizational performance (Caldwell 2003; Truss 2013; Ulrich \& Brockbank 2005). However, there have been problems in adopting a business perspective. The status of HR practitioners as a professional group has long been considered unstable and capricious. This is apparent in both private and public organizations (Farndale \& Hope-Hailey 2009; Gubbins \& Garavan 2016; Lindström \& Vanhala 2011; Pohler \& Willness 2014; Truss 2008).

Since the turn of the millennium and during its first decade (2000-2010), societal developments in Finland spurred increasing interest in well-being at work alongside productivity and overall performance. Socio-political and financial demands formed institutionalized discourses of high performance and well-being at work. Institutionalized discourses are historically situated and rather standardized ways of referring to phenomena which are coupled to identifiable institutions.

The discourses of high performance and well-being at work were discernible in the operations of various institutions, especially during the first decade of the 200os. Discursive examples emphasizing forms of high performance and/or aspects of well-being at work can be found in the media (Väänänen \& Varje 2014), policy-making (Kivistö et al. 2014), research funding (Academy of Finland 2014), academic and applied research (Vanhala et al. 2012), and the work of employer organizations and trade unions (Local Government Employers 2007a, 2007b; 2008; Productivity Round Table 2011), governmental organizations (Anttonen \& Räsänen 2008; Kangasharju \& Pääkkönen 2010) and municipalities (Lindström \& Vanhala 2011). Studies show that these society-level discourses both restrict and provide opportunities for professionals to position themselves. Consequently, professionals can be seen as active and resourceful agents who employ various different discourses to suit their purposes (Hall 1996; Kuhn 2009; Mumby 2005).

Finnish municipal organizations have been characterized by wide-ranging structural changes and performance-driven management practices in the spirit 
of New Public Management (NPM) since the end of the 1980s. In the 200os, continuing demands for high performance coupled with extensive mergers have shaped the working environment of the municipal workforce, including HR practitioners.

The situation in public organizations during the past decade - in which HR practitioners with uncertain status have faced institutionalized demands for well-being at work and high performance - forms a compelling setting for this thesis. Through this study, my aim is to enhance our understanding of how HR practitioners position themselves in a municipal context characterized by institutional demands for high performance and well-being at work. I employ a discursive perspective (Fairclough 2003; van Leeuwen 2008; van Leeuwen \& Wodak 1999; Wodak \& Meyer 2009) to fulfill this aim. This means that I perceive professional positions as constructed discursively by both professionals themselves and actors in their surroundings. Through an empirical study in which I qualitatively analyse interviews with Finnish HR practitioners, I specifically focus on the professionals themselves and ask the following question: How do HR practitioners use discourses to strengthen their position in municipal organizations?

The work and role of HR practitioners is a loosely coupled research area within organization and management studies (e.g. Keegan \& Francis 2010; Pohler \& Willness 2014; Renwick 2003; Storey 1992; Ulrich 1997). I use the term HR practitioner to refer to a person who is involved in the management and/or development of people in work organizations. The work involves planning, maintaining, developing and organizing the work of others. HR practitioners can be either so-called generalists or specialized in areas such as competence, salaries and benefits, staffing, administration and well-being. In large organizations, they usually form an organizational unit termed the HR department or HR function. HR practitioners also include people in supervisory positions within these functions.

\subsection{Background}

During the early days of the profession in the late 180os, HR practitioners were called welfare secretaries and were employed in large industries (Barley \& Kunda 1992). At the time, the concern of welfare secretaries in these paternalistic industries was for overall welfare, housing, hygiene and recreation - areas now coupled with social work (Barley \& Kunda 1992; Jacoby 2004; Morley et al. 2006). Also, early Finnish industrial organizations, for example Imatran Voima in the 1920s, provided health care for workers and schooling for their children (Auer \& Teerimäki 1982).

During the first half of the 2oth century, 'early HR work' increasingly focused on ensuring safe working conditions and preventing labour-market disputes. During the 1960 s and 1970s, calls for increasing participation in work organizations, improving psychological and physical work conditions, and promotion of occupational health strengthened in the Nordic countries (Wainwright \& Calnan 2002) and hence became part of the agenda of HR practitioners of the time. 
Before the 1990s, public sector organizations and their respective HR functions were regarded as model employers that promoted fairness, equality and stability in employment relationships. Practices that mirrored these ideals included, for example, high levels of job security, internal career paths, promotion based on seniority, and predictable trends in salary (Brown 2004; Colley et al. 2012; Morgan \& Allington 2002).

However, this type of management was considered inefficient by the end of the 1980 s. Ideals and practices linked to the model employer image were challenged by NPM thinking according to which they undermined performance and lack sufficient rewards for individual contribution (Colley et al. 2012; Truss 2008). Additional pressures stemmed from local and national governments that criticized the quality of public services and propagated an ideology that favoured competition and private sector management (Bach \& Kessler 2007). Simultaneously, HRM (Human Resource Management), as a distinct approach to employment management, had entered and gained favour in Finnish work organizations (Kuokkanen et al. 2010; Vanhala 1995). Consequently, HR practitioners as a professional group in public organizations were targeted by pressures from local and national governments to adopt NPM managerial logics, to become more business-like and, hence, contribute to individual, organizational and financial performance (Bach \& Bordogna 2011; Bach \& Kessler 2007; Harris 2007; Truss 2008; Truss 2013). Most of the literature on HR roles from both public and private sectors show that the interest of HR practitioners shifted from employee well-being towards strategy and performance (Francis \& Keegan 2006; Harris 2007; Hope-Hailey et al. 2005; Keegan \& Francis 2010; Kochan 2004; Renwick 2003; Watson 2007; Woodall \& Winstanley 2001). However, there are examples of HR practitioners in Finland which show their particular interest in well-being at work (Luoma \& Viitala 2015; Viitala \& Järlström 2014).

The concept of performance requires some introduction and clarification. Simply stated, performance includes multiple aspects of accomplishing something faster, cheaper or somehow better. Terms such as productivity, efficiency, and cost-effectiveness can be viewed as parts of performance. In public organizations, performance is considered more diverse than in private settings. It covers aspects such as governance, service quality, democratic outcomes and equality (Pollitt \& Bouckaert 2004; Walker \& Boyne 2009). In the Finnish municipal sector, Local Government Employers (2008) defined performance as follows: 'High performance means a municipality's ability to organize services in a financially sound way regarding effectiveness, service quality, process flow and employee capability.'

Also, the concept of well-being at work needs to be clarified. A typical definition of well-being at work ranges between three dimensions, physical (e.g. ergonomics), psychological (e.g. exhaustion, engagement) and social (e.g. atmosphere, levels of trust) (Dodge et al. 2012). Associated concepts are, notably, job quality (Findlay et al. 2013; Martel \& Dupuis 2006), work ability (Tuomi et al. 1998), and wellness at work (Cederström \& Spicer 2015; Farrell \& Geist-Martin 2005). These concepts, however, stress partly different aspects. While job qual- 
ity encompasses workers' rights and fair pay, well-being at work is often separated from pay, which is left to collective bargaining. Wellness and work ability, on the other hand, often refer solely to the physical and psychological aspects of wellbeing, ignoring the social level (Mamia 2009). During the first decade of the 200os, well-being at work to some extent replaced or incorporated these other concepts as an umbrella term.

Public sector HR practitioners have encountered difficulties in adopting the performance-oriented and strategic role often required of them by the HRM approach and NPM ideology, making their position precarious and fragmentary (Alfes et al. 2010; Farndale \& Hope-Hailey 2009; Truss et al. 2002; Truss 2008). The position of HR practitioners is affected by a plethora of external and internal demands and expectations. These include public sector reforms, governmental approaches to assessment public sector organizational performance (Harris 2007; Truss 2008) and the expectations of relatively powerful stakeholders such as politicians, trade unions and employer organizations (Knies et al. 2018; Truss 2008).

Expectations for a strategic role stem from HR practitioners themselves, while senior and line managers within organizations also expect more explicit contributions (Truss 2008). Furthermore, the public sector context is characterized by the absence of a shared meaning for strategic HRM. Large organizations have a multitude of different kinds of service production, which complicate the function's strategic ambitions (Truss et al. 2002). Other contributing factors to the fragmentary position of HR practitioners are scarce resources allocated to HR departments and the sometimes unfavourable image of HR work (Farndale \& Hope-Hailey 2009; Truss et al. 2002). Finally, public sector HR practitioners confront 'red tape'; established practices can be slow and difficult to alter (Knies et al. 2018).

In Finland, the focus on well-being at work strengthened and it became a societal area of interest during the past decade, i.e. between 2000 and 2010 (Blom \& Hautaniemi 2009). While well-being at work has been anchored in Finnish society during decades-long cooperation between labour market institutions, the emergent interest in well-being was different in its link to intensified efforts to increase productivity (Findlay et al. 2013; Mamia 2009). National and local governments argued for the need to increase productivity, especially because the proportion of senior workers in Finnish as in other Nordic municipalities was growing (Lindström et al. 2008). Further, Findlay et al. (2013) explain the renewed popularity of well-being at work with its potential economic and social benefits such as innovation. In the Finnish context, policymakers and labourmarket organizations alike adopted well-being at work as a key concept for improving the quality of working life and various well-being initiatives, projects and programmes were initiated (e.g. Ministry of Employment and the Economy 2012; Ministry of Social Affairs and Health 2005; Productivity Round Table 2011). Moreover, media, research and policy interest in the financial impact of ill-being at work through, for example, absenteeism and early retirement, spurred employers to implement diverse well-being programmes and practices in work organizations. 
Even though the rhetoric of HRM and HR practitioners highlights the uniformity of employer and employee interest, friction between values and goals pose a persistent dilemma for HR practitioners (Woodall \& Winstanley 2001). The simultaneous objectives of high performance and well-being at work are considered difficult to combine in HR work when HR practitioners had to move from 'rhetoric to reality'. Organizational and individual performance expectations coupled with employee health and well-being represent potential sources of role conflict, as they often advocate these differing interests (Harris 2007; Keegan \& Francis 2010; Legge 2005). To illustrate this, Renwick (2003) described HR practitioners as both 'guardians' and 'gamblers' in employee wellbeing.

\subsection{Research focus}

This thesis addresses HR practitioner positioning in a municipal context by leaning on two previous research literatures: the literature on HR roles and the literature on professional positioning. I refer to these areas of study as 'literatures' as they are not limited to one clear theory. Instead, they represent a coherent set of studies which have a common object of study or a shared conceptual basis. Together they form the theoretical backbone of the thesis. Next, I elaborate on the needs for further research in the two literatures which this thesis specifically aims to address.

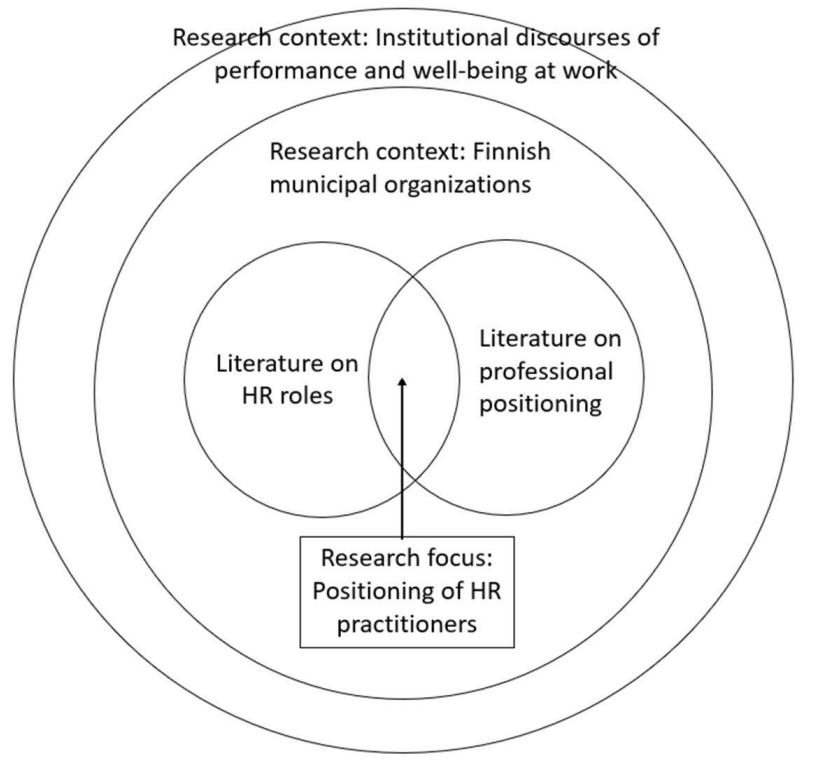

Figure 1. Summary of the research context, theoretical perspectives and research focus of the thesis.

Firstly, in the diverse literature on HR roles (e.g. Keegan \& Francis 2010; Storey 1992; Ulrich 1997; Renwick 2003), insufficient attention has been given to the 
institutional context in the construction of HR practitioner roles. While performance and well-being at work have previously been identified as central phenomena in relation to the work of HR practitioners, they have been studied more as objectives and aims than contextual factors (Boselie et al. 2005; Wall \& Wood 2005). Recently, more calls for studying the work of HR practitioners by giving more attention to their institutional contexts have been raised (Lewis et al. 2019).

Moreover, contextual studies of professionals who identify with multiple discourses in specific historical and institutional contexts are few in number (Hall 1996; Kuhn 2009; Mumby 2005). Such studies show the creative, adaptive capacity of professionals in the midst of discourse (Kuhn 2009). Kuhn (2009) views professionals as active, self-reflexive and resourceful nodes where different discourses meet. A somewhat similar research setting is used by Zanoni and Janssens (2004), who show how HR practitioners employ the discourse of diversity, which was becoming part of Belgian governmental and corporate discourses on employment at the time of their study. However, to my knowledge, the positions of HR practitioners have not been studied in a setting with multiple institutionalized discourses.

The bulk of previous studies on both performance and well-being in relation to HR work has been functionalist in character, i.e. aimed at questions such as how HR practitioners can decrease work-related stress and improve organizational and individual performance through the development and devolution of certain practices. Instead of focusing on finding correlations or causal explanations between HR practices and desired outcomes, HR scholars are urged to move on to a deeper understanding of subject matter through qualitative materials and by taking contextual variations into consideration (Hesketh \& Fleetwood 2006; Janssens \& Steyaert 2009).

Demands for enhancing performance and well-being at work in public sector organizations create a situation where HR practitioners are required to evaluate and reconstruct their own work and position in organizations. Furthermore, the context of municipal organizations is a called-for research setting, since HR practitioners and HR functions in the public sector have not received as much attention from scholars as their private sector counterparts (Brown 2004; Gould-Williams 2007; Knies et al. 2018).

The possibility of a deeper contextual understanding is the advantage of discursive research approaches. However, studies that adopt a discursive perspective and scrutinize how HR practitioners themselves use language to construct their position are few and far between with the exception of Keegan and Francis (2010), Wright (2008) and Pritchard and Symon (2011). Watson (1995) points out that the concepts in particular and the HRM language in general used by managers and members of professional groups can be seen as discursive resources which the language users employ in their everyday, occupational work and in making sense of their identities as well.

Furthermore, there is ongoing discussion within research on HR practitioners regarding whether and how HR practitioners engage with performance or wellbeing at work. The research field needs new perspectives and empirical cases 
which enrich the portrait of HR practitioners as a professional group. Research on HR roles shows that HR practitioners increasingly aim to strengthen their position by focusing on how they could contribute to the individual, team and organizational levels of performance. Another stream of studies perceives that the importance of well-being at work might in fact grow side by side with the focus on performance. Research on HR practitioners needs a better understanding of the contextual variations and the institutional environments that provide them with both constraints and opportunities to position themselves professionally.

Also, there is a need to deepen our understanding of the relational aspect of professional positioning of HR practitioners. While the importance of relations with internal stakeholders such as line managers and top managers is acknowledged and given considerable attention (Guerci \& Shani 2013; Janssens \& Steyaert 2009; Järlström et al. 2018; Paauwe 2009), the focus has seldom been on HR relations with actors outside immediate organizations such as local communities and public policymakers (Cleveland et al. 2015; Ferrary 2008).

\subsection{Aim of the study}

In this thesis, I study how HR practitioners in municipal organizations construct positions for themselves in a context characterized by the institutionalized discourses of high performance and well-being at work. Particularly, I focus on the positions reflected and constructed by HR practitioners in relation to them. Consequently, the following is the main, overarching research question of this thesis:

How do HR practitioners use discourses to strengthen their position in municipal organizations?

The overarching research question is answered through three published studies which shed light on three sub questions:

1. How is the positioning of HR practitioners aimed towards other actors in municipal organizations?

2. How does the positioning of $H R$ practitioners reflect and employ the institutional discourse of performance?

3. How does the positioning of HR practitioners reflect and employ the institutional discourse of well-being at work?

This thesis contributes to enhancing our understanding of the way HR practitioners construct their professional positions. It contributes to the literature on HR practitioner roles in three ways. Firstly, it argues for the importance of considering the institutional context when exploring how HR practitioners position 
themselves. Secondly, it highlights the relational aspect of HR practitioner positioning, and finally, deepens the discussion of HR interest in well-being at work.

Furthermore, this thesis contributes to the literature on professional positioing in two ways. Firstly, by answering the calls for a richer contextual understanding in studies of professional positioning and, secondly, by providing new insight to the literature by combining the framework of discursive legitimation with the analysis of professional positioning.

\subsection{Structure of the thesis}

This thesis consists of two parts. Part I is this introductory essay while part II consists of three published research articles.

In this chapter I have introduced the thesis and briefly presented the calls for research it aims to fulfill. Also, I have stated the aim of the thesis and defined the research question. Next, I move on to articulate how previous research has studied professional positioning in general and HR roles in particular. Thereafter, I sketch the background and context of the study by describing the municipal context and institutionalized working life discourses of high performance and well-being at work that developed and strengthened in Finland between 2000 and 2010. Then I present the methodological considerations. In the results section, I briefly present how the three empirical studies answer the research question and how they contribute to the overall aim of the thesis. The thesis ends with a concluding section where I pull all the strings together, elaborate on the contributions, discuss the practical implications and sketch possible designs for future research.

Part II contains the articles on the three studies included in this thesis. They are published in the journals of Public Management Review, Baltic Journal of Management and Scandinavian Journal of Management. 


\section{Studying professional positions}

By professional position I refer to a professional group's stance in an organization: a standpoint from which to achieve goals and exert influence by, for example, promoting certain values and practices within an organization. Positions are characterized as altering standpoints from which to speak and act; they are often discursively constructed by the position holders themselves in relation to others (Maguire \& Hardy 2009; Thomas \& Davies 2005). Other studies have used concepts such as role identity (Goodrick \& Reay 2010; Rao et al. 2003), identity position (Carollo \& Guerci 2017), subject position (Kuhn 2009; Thomas \& Davies 2005) and professional identity (Roche \& Teague 2012; Wright 2008) to conceptualize the phenomena where occupational groups use language to construct their stance in organizations and society. Some studies use these concepts almost as synonyms (Pritchard \& Symon 2011).

My choice of using the concepts of professional position and positioning in this thesis is motivated by how 'professional' connotes certain groups in working life, and 'position' connotes something that is constantly changing. The concept of professional role, for example, is attached to the rather stable values, norms and interactions associated with being a professional (Ashforth 2001; Chreim et al. 2007; Goodrick \& Reay 2010). Previous studies, however, show that HR practitioners occupy several 'roles' simultaneously (Truss 2008; Ulrich 1997). This view of simultaneousness and the importance I give to discourse in the process guide me to use the 'fluid, dynamic and relational' notion of position (Harré \& van Langenhove 1999) in understanding the process. In the first study of this thesis (Lindström \& Vanhala 2011), we used the concepts of role and position as synonyms. In this introductory essay, however, I have decided to employ the concept of professional position instead of professional identity or professional role when presenting my work.

In understanding how professional positions are constructed, I draw from the literature on subject positions (Fairclough 1992; Maguire \& Hardy 2009; Törrönen 2001; Törrönen 2013). Subject positions are vantage points that shape how we understand social reality, how we act in it and how we might influence it (Fairclough 1992; Maguire \& Hardy 2009; Phillips \& Hardy 1997). Building upon the work by Hall (1996), Törrönen (2001; 2013) specifically argues for the aspect of discourse in the analysis of subject positions; they are historically, socially and culturally produced through language use (Törrönen 2001; Törrönen 2013). Further, the concept of subject position encapsulates both structure and 
agency, as individuals are simultaneously confined by structures which prescribe certain positions, and creative interpreters of their own positions within these structures. Self-positioning implies agency - the subjects themselves reflect upon, resist and mould their positions though varying identifications (Knights \& Willmott 1989; Törrönen 2001).

Furthermore, my approach to studying professional positions is influenced by neo-institutional theory. Its framework of institutional work, which, for example, studies how different professional groups develop and transform institutions, is relevant for my understanding of professional positioning because of their focus on the strong agency of professional groups in institutional environments (e.g. Daudigeos 2013; Lawrence \& Suddaby 2006, Suddaby \& Viale 2011).

In this chapter, I present the principal theoretical perspectives in which this thesis is anchored: the literature on professional positioning and the literature on HR roles. In the following, I present my understanding of how professional positions are discursively constructed, map out HR practitioners as a professional group, and describe how previous research has tackled the questions of their professional position and positioning.

\subsection{Professional positioning}

Next, I present three perspectives on professional positioning relevant for this thesis: the importance of positioning oneself towards other actors, the importance of positioning oneself in relation to broader, institutionalized discourses, and, most prominently, the agency of professionals themselves in this construction work. I exemplify these perspectives by referring to previous empirical studies.

Firstly, positioning is a relational process. The way actors talk about and refer to others is a key part of constructing their own positions. Actors make sense of themselves in relation to others through boundary construction which means that how they talk about others, they come to construct, by implication, who they are themselves and who they are not (Ybema et al. 2009). This positioning is a value-laden process influenced by 'social maneuvering and power games' often connected to social, political and economic interests (Ybema et al. 2009, 307). Daudigeos (2013), for example, shows how occupational safety and health managers exert influence inside their organizations by rhetorically constructing internal and external relations to make up for their low formal status. They have been successful in building alliances with other members of the organizations, for example from the sales department, which, unlike HR, is considered core business.

This leads us to the second perspective relevant for this thesis. I acknowledge the importance of positioning oneself in relation to broader socio-cultural structures such as institutionalized discourses. From the literature on subject positions, we know that positions in general are shifting constructs. Actors construct and adopt certain positions depending on which culturally or socially valuable competences are linked to them. This means that agents change their positioning depending on the situation. Specifically, positions offer certain viewpoints 
on how to act in concrete situations (Törrönen 2001). However, the situational and contextual character of subject positions entails that they sometimes reflect fragmented and contradictory identifications. This is shown, for example, by Kuhn (2009), who argues that most studies on professional positions do not give enough importance to context. When studying professional positions, understanding broader, institutionalized discourses is essential because they are the foundation for professional activity in organizations.

Studies which concentrate on how professional groups position themselves in relation to institutionalized discourses in their context have investigated lawyers and the discourse of managerialism (Brown and Lewis 2011; Kuhn 2009), sustainability managers and the climate change discourse (Wright et al. 2012), professional chefs and the discourse of nouvelle cuisine (Rao et al. 2003), public service professionals in the police, social services and education, and the discourse of NPM (Thomas \& Davies 2005). Studies which have focused on HR practitioners and their positioning in relation to strong discourses in their work environment are rare. One of the few examples is set by Zanoni and Janssens (2004), who studied how HR practitioners operate within the discourse of diversity, which at the time of the study was becoming part of Belgian governmental and corporate discourses on employment.

Thirdly, in understanding how actors construct their professional positions I adhere to the thought that actors are both constrained by institutions such as certain discourses and structures and creative interpreters of them (Törrönen 2001). The notion that individuals are overpowered by and passively adopt certain subject positions from e.g. management discourses (Ackroyd \& Thompson 1999; du Gay 1993; Willmott 1993) is questioned by research stating that people are, in fact, actively involved in creating certain positions from which to speak and act through adaptation and reconstruction of positions offered in discourse. People problematize, reinforce and reconstruct the kinds of positions which are considered legitimate or normal in certain situations and discourses and which are not (Maguire \& Hardy 2009; Phillips \& Hardy 1997; Thomas \& Davies 2005). I discuss this active perspective to professional positioning further in the next section.

\subsubsection{Understanding professional positioning as an active process}

If we take a look at what previous studies have stated about the positioning of professionals, we see that legitimacy and credibility are something continuously constructed and performed by professionals themselves (Collinson 2003; Daudigeos 2013; Pritchard \& Symon 2011). Like Kuhn (2009), I consider that positioning is accomplished at a 'meso' level. This means that positioning is a combination of two aspects: 1) situational and local discursive practice and 2) resources drawn from institutionalized discourses. In his study of how corporate lawyers position themselves through institutionalized discourses of both managerialism and legal professionalism, Kuhn (2009) shows how the agents use different discursive resources (concepts, expressions or other ways of language use) as a combination of both situational, local discursive practices and discursive resources drawn from institutionalized discourses. 
Previous studies show that professional groups can turn to, adapt and subvert institutionalized discourses, especially in situations when their position is threatened, and they aim to claim a specific area of expertise (Brivot 2011; Brown \& Lewis 2011; Rao et al. 2003; Thomas \& Davies 2005). Brivot's (2011) study shows how law professionals were initially threatened by institutional pressures for more accountability and bureaucratization of their work in the form of a centralized knowledge management system. The study shows strategies with which they retained their professional independence and control over knowledge by redefining their work. For example, they used the system for selftraining to monitor their peers and territorialize areas of expertise. In another study on lawyers, Brown and Lewis (2011) show how they are confronted with the discourse of managerialism, which is reflected in their required timekeeping and billing routines. Lawyers subjugated to this discourse, but also adapted their position in relation to it by incorporating personal judgement, taste and discretion regarding how they carried out these managerially induced routines.

Another example is provided by Rao et al. (2003), who explain how professional chefs adopted the culinary discourse of nouvelle cuisine and established new institutional logics and an altered professional position for themselves in the restaurant world. They transformed themselves from technical executors of classical dishes to innovators. In another study, Wright et al. (2012) show how sustainability managers applied the discourse of climate change to construct different discursive positions, and partly challenge the dominating discourse of economic growth.

In a study of the UK public sector, Thomas and Davies (2005) investigate how public service professionals in the police, social services and secondary education position themselves in relation to the discourse of NPM. They identify four ways which provide detail for our understanding of how NPM is adopted and adapted at the level of public sector professionals. Firstly, they identify a position where the professionals portray themselves as strategic, market-oriented and having leadership skills. Secondly, they identify a position mirroring competitiveness and aggression. Thirdly, they find a position which is disempowered in the face of the new demands of NPM and, lastly, a position which leans on 'softer' leadership attributes than a competition- or market-orientation such as support, coaching and mutual respect. The positioning of these professionals is partly a subtle and complex form of resistance to the NPM discourse. Professionals position themselves in relation to it through a dynamic, sometimes conflicting process of resistance and reproduction.

Kuhn (2009) identifies four ways in which corporate lawyers position themselves in a context encompassing two institutional discourses: managerialism and legal professionalism. Firstly, the lawyers deny the influence of managerialism and defend themselves by stressing the complexity and sophistication of legal work through a strong identification with the legal professionalism discourse. Secondly, they simultaneously agree to the managerialism discourse and distance themselves from it by using their employer as a shield. In other words, they adhere to managerialism because the organization demands it. Thirdly, the lawyers combine the two discourses but this time they legitimate adhering to 
the managerialism discourse by referring to each lawyer's personal traits and choices. Finally, the lawyers refocus themselves, and law in general, as a positive force. It is through the discourse of managerialism and especially the resources of a large firm that the values of legal professionalism can be harnessed to serve social welfare.

While not referring to a particularly dominating or institutionalized discourse in their environment, a few studies of HR practitioners have looked at how they are active interpreters in situations where they are confronted with a different, new kind of way of working (Pritchard \& Symon 2011; Wright 2008). Wright (2008) studied how HR practitioners interpret the adoption of a business partner role where they work as internal consultants and advisers to managers. While they experience a strengthened position in the organizations with higher legitimacy for their work as individuals, they distanced themselves from HR as a profession per se. To them, HR affiliation meant bureaucracy and administration - the 'antithesis of the desired strategic identity' they were after (Wright 2008, 1081). In another study, HR practitioners were assigned a less favorable role as call center representatives, specifically as advisers to employees in a shared service center. Here, they worked as more reactive information handlers compared with the strategic role of so-called HR business partners. In the process, they constructed and legitimated their position anew. In positioning themselves as valuable and legitimate professionals in the new context of call center work, they use three ways: Firstly, they highlighted the complexity of their work and their own esoteric knowledge in handling it. Secondly, they stressed the added value to the organization generated through their work, and, thirdly, they emphasized their professional uniqueness in being close to and supporting employees in problem solving (Pritchard \& Symon 2011).

While discursive legitimation is a framework often applied to understanding the legitimation of different practices and organizational forms (for example, Vaara \& Tienari 2008), a couple of studies have also identified discursive legitimation as a distinct strategy for professional groups in building their own position (Goodrick \& Reay 2010; Lawrence \& Suddaby 2006). Goodrick and Reay (2010) identify five ways of discursive legitimation in understanding the changing role identity of registered nurses. These include naturalizing the past, normalizing new meanings, altering identity referents, connecting with the institutional environment and referencing authority. Despite the huge interest targeted at discursive legitimation during the past decade, its potential as a framework for understanding professional positioning has not yet been explored.

\subsection{The shaky position of HR practitioners}

Early literature on HR practitioners has been highly prescriptive in focusing mainly on what HR practitioners and the HR function should be like, what they should focus on and how they should operate (Storey 1992; Tyson \& Fell 1986; Ulrich 1997; Ulrich \& Brockbank 2005). These as well as more current studies mostly use the concept of role when describing HR positions in organizations. 
Hence, in this section the terminology used alters depending on the concepts used in the original literatures.

As a prominent example of the prescriptive style, Ulrich's (1997) well-known framework argues for a fourfold typology of roles: strategic partner, administrative expert, employee champion and change agent. Ulrich (1997) suggests that together, these roles deliver competitive advantage and add value to organizations. However, simultaneous implementation of different roles has led to role ambiguity, contradictions and tensions among HR practitioners (Caldwell 2003; Gubbins \& Garavan 2016; Pohler \& Willness 2014).

In the wider frame of occupations and professions, HR practitioners belong to the category of organizational professionals, i.e. people who use their professional knowledge in solving problems of managerial and commercial importance (Adler et al. 2008; Evetts 2011; Faulconbridge \& Muzio 2008; Reed 1996). The emergence of these organizational professionals is the result of the division of expert labour in large, hierarchical corporations during the last century (Reed 1996). Besides HR practitioners, there is growing interest in studying the roles of organizational professionals such as accountants (Burns \& Balvinsdottir 2005), occupational safety and health managers (Daudigeos 2013), internal consultants (Wright 2009), and CSR managers (Carollo \& Guerci 2017).

Developments in the work and position of HR practitioners are partly explained by the strengthening of organizational professionalism. In the context of NPM-inspired public sector reforms, groups of public sector professionals have internalized new kinds of organizational priorities such as strengthened accountability and customer orientation in their language use and other activities (Evetts 2006).

Organizational professionalism is a rather recent conceptualization of groups of occupations in society. It differs from earlier understandings of professionalism since it is characterized by managerial priorities replacing or adding to the guiding values of occupations. Also, the knowledge of organizational professions is often contingent and organization-specific (Reed 1996). This is in sharp contrast to building on the independent, collegial professional standards and abstract knowledge characterized by the traditional, occupational forms of professionalism (Evetts 2011; Faulconbridge \& Muzio 2008).

In early studies of professions during the 1950 s and 1960s, professionalism meant characteristics distinguishing professionals from other occupations (Etzioni 1969, Greenwood 1957). These early definitions of professionalism focused on classic professions like law and medicine. In the 1970s, the view of professionalism as something an occupation either has or does not have reached its limits, and a view of professionalism as a way to organize and control an occupation, often as a political project, developed (Freidson 1970, Larson 1977). Freidson (2001) views professionalism as a third logic alongside the logics of the organization and the market and argues that new, large and complex organizational contexts of work diminish the value of professionalism and increase that of managerialism and entrepreneurship. 
Definitions of organizational professionalism, on the other hand, assume that it is not an either-or game. In organizational professionalism, groups of people employ, combine and adapt organizational priorities, occupational norms and other institutional demands to possible challenges and opportunities which emerge in organizations (Adler et al. 2008; Faulconbridge \& Muzio 2008; Reed 1996). Even so, organizational professionals can have difficulties in changing organizational norms, beliefs and practices. According to Daudigeos (2013), they often have an ambiguous status and lack authority and legitimacy in exerting influence. Consequently, members of these organizational professions continuingly need to showcase their expertise and assert their abilities to solve important problems in order to maintain their influence and resources in the organizations (Reed 1996; Wright 2008). As in the case of other organizational professionals, the position of HR practitioners as important and legitimate professionals in organizations is a recurrent concern for them and an established research venue for the academics studying them (Legge 2005; Wright 2008).

A historical explanation as to why HR practitioners experience a lack of status and a volatile position is in their background as organizers of paternalistic 'welfare work' (Legge 1978). Another perspective on the lack of status and authority experienced by HR practitioners can be the steady feminization of the profession. In Finland in the 1960 s few women served as social or training managers. However, by the middle of the 2010s, women accounted for over 80 per cent of HR practitioners. Despite festive announcements of the strategic importance of HR work, it is often perceived as less important than the 'real' strategic work carried out by line and top managers (LaPointe \& Tienari 2015). What is surprising about this lack of status is that in fact, HR practitioners work with financially substantial operations such as recruitment, competence development and the work organization of people. Large organizations, such as cities, may employ tens of thousands of people and, consequently, invest massive resources in personnel.

HRM with its core belief in employees as a valuable resource in which you can and should invest has its roots in the Human Relations school of thought which emerged and gained a foothold in management during the first half of the 20th century (Kuokkanen \& Seeck 2007). This development reached Finland in the end of the 1950s, when personnel administration as an area of specialized management practices with designated specialists started to take shape. This was backed up by thinking that employee matters should be invested in, planned and coordinated rationally (Lilja 1987). At the time, 'early HR work' was not performed by HR practitioners, but by 'social managers'. In Finland, the first association for the professional group, The Society of Social Managers, was founded in 1946 (Leppävuori 2015). During the 1960s and 1970s, calls for increasing participation in work organizations, improvements in psychological working conditions and physical environments, and the promotion of occupational health strengthened in the Nordic countries (Wainwright \& Calnan 2002), which made them part of the agenda of the HR practitioners of the time. Lilja (1987) describes the 1970s as the decade when personnel administration 
as the work of 'personnel specialists' in Finland strengthened belief in the importance of the profession. At the time, the organizational context in Finland was characterized by a shortage of qualified workers, high levels of turnover, and an increased number of labour-market disputes. Employer organizations, management developers and publishers published copious material on personnel administration at the time. Also, early HR practitioners organized themselves around professional development in professional associations. The first one, Helsinki Training Managers, was founded in 1957. The second association, the Society of Personnel Managers, started in 1964. In 1973, they changed their name to the Association of Personnel Managers (Leppävuori 2015).

\subsubsection{HR practitioners, high performance and well-being at work}

Before the 1990s, public sector organizations and their respective HR functions were deemed as model employers that promoted fairness, equality and stability in the employment relationship. Practices that mirrored these ideals included high levels of job security, promotion based on seniority, and predictable trends in salary (Morgan \& Allington 2002). However, these ideals and practices were challenged by NPM thinking, according to which they undermined performance and lacked sufficient rewards for individual contribution (Truss 2008). In the mid-1980s, HRM as a distinct approach to employment management had entered Finnish work organizations (Kuokkanen et al. 2010; Vanhala 1995). HRM emphasizes employees as valuable resources to invest in and develop, proactive strategic orientation in employee management on behalf of HR practitioners, strong line management responsibility and concern for performance (Guest 1987; Storey 1992). In 1990, Finnish HR practitioners saw that the time was right to merge the two professional associations into one - HENRY: the Finnish Association for Human Resource Management - which was more in tune with the demands of the time (Leppävuori 2015).

In public organizations, HR practitioners were targeted by pressures to adopt NPM managerial logics; they were to become more strategic and business-like and hence be able to contribute to individual, organizational and financial performance (Bach \& Bordogna 2011; Bach \& Kessler 2007; Harris 2007; Truss 2008; Truss 2013). In the Finnish public sector, these pressures arose from the economic recession in the beginning of the 1990s, which ended expansion of the public sector and introduced demands for privatization and rationalization. Amidst these changes were HR practitioners, who were both implementers and targets of the new policies (Vanhala 1995).

Continuously topical performance expectations stem from both inside and outside the organizations. Inside the organizations, senior and line managers expect more explicit contributions from the HR function. Furthermore, HR practitioners themselves appear to have internalized these demands and expectations (Truss 2008). Moreover, the typically large size and complexity of public organizations complicates the function's strategic ambitions (Truss et al. 2002). The outside demands originate for example from governmental approaches in reviewing public sector organizational performance and governmentally imposed reforms (Harris 2007; Truss 2008). Moreover, politicians, trade unions 
and employer organizations are strong stakeholders who assert demands on public sector HR practitioners (Knies et al. 2018; Truss 2008). Other pressures stem from the scarcity of resources allocated to the department and the sometimes unfavourable image of HR work (Farndale \& Hope-Hailey 2009; Truss et al. 2002). Finally, the operating culture in many public sector organizations is characterized by 'red tape', which means a context where altering established practices is a slow and difficult process (Knies et al. 2018).

So far, the dominating HRM perspective has argued that adopting a business partner role which contributes to organizational performance is the key to improving the status of HR practitioners (Caldwell 2003; Ulrich \& Brockbank 2005). However, difficulties in responding to pressures to become more strategic and contribute to performance has made the position of HR practitioners precarious and unstable (Farndale and Hope-Hailey 2009; Gubbins \& Garavan 2016; Pohler \& Willness 2014; Truss et al. 2002). In a study from the public sector, Truss (2008) shows that the roles adopted and adapted by HR practitioners are not polar opposites. This means that they are not either-or, for example strategic or non-strategic. Instead, different roles are performed at different times and in different areas of activity. Hybrid and complex forms of HR roles combine and adapt elements stemming from the traditional public sector model and NPM-inspired elements derived from the private sector.

While the interest of both public and private sector HR practitioners shifted towards strategy and performance, studies show their decreasing interest in the responsibility and concern for the well-being of employees (Harris 2007; Keegan \& Francis 2010; Renwick 2003; Watson 2007; Woodall \& Winstanley 2001). Prior studies identify the demands for performance and well-being at work as potential sources of role conflict, as they often represent differing values (Harris 2007; Legge 2005; Renwick 2003; Woodall \& Winstanley 2001).

Two potential ways for HR practitioners to deal with this conflict are identified. First, well-being and other employee-centred activities are marginalized (Keegan \& Francis 2010; van Buren et al. 2011). Keegan and Francis (2010) point out that HR practitioners shift the logic of their work from a pluralistic view of the employment relationship to a business-centred view, because the business partner label comes with an improved professional status.

As a second response to the role conflict, some studies argue that well-being at work and employee-focus in general might in fact be strengthened alongside a business-centred role (Arrowsmith \& Parker 2013; Roche \& Teague 2012). To clarify, since the performance-oriented role reinforces the status of HR practitioners, they are able to incorporate 'softer' values under the wing of performance. Arrowsmith and Parker (2013) show that the conflict between performance and well-being does not necessarily erase the latter from HR work. They studied the implications of bringing in employee engagement as a value and an objective for the work of HR practitioners in a large postal organization. As a result, they show how HR practitioners 'back up' engagement with an evidencebased approach, which shows how engagement benefits performance. This is done in order to sell engagement as a value and goal to top managers. However, they argue that engagement is not simply used as a smokescreen for stressing 
performance. It also restructures HR roles based on increasing pluralism where 'hard' and 'soft' elements are combined.

Roche and Teague (2012) argue that during the economic recession in Ireland, which started in 2008, HR practitioners did not abandon their professional values and ethical concerns. Traditional ideals of fairness and good communication with employees persevered even though HR practitioners were involved in improving the performance of organizations through retrenchments and despite HR functions being downsized themselves. In sum, HR practitioners blended their business-centred role with employee advocacy. The profession gained influence in organizations due to their important knowledge and skills in people management, which were in high demand during the recession. 


\section{Institutionalized working life discourses in the Finnish municipal context}

Finnish municipalities have undergone numerous changes during the first decade of the 2000s including mergers as well as financial cutbacks. In the public sector in general, discourses of performance and well-being at work strengthened and were targeted towards professionals. In this section I present the context of municipal organizations and the institutional discourses of high performance and well-being at work.

\subsection{Municipal organizations as a research context}

The context of this thesis is the Finnish municipal sector, where different types of service networks and organizations, fairly autonomous decision-making systems based on municipal self-government and governmental steering mechanisms constitute the operational environment of HR practitioners. In 2018, there were 311 municipalities in Finland (Association of Finnish Local and Regional Authorities 2019). The organization 'Local Government Employers' represents the interests of municipalities and joint municipal authorities as employers.

Municipal organizations are typically large employers with a focus on service production. The city of Helsinki, for example, is the largest employer in the country with over 40,00o employees. Finnish local and regional authorities employ approximately 419,000 persons, which is 20 per cent of Finland's workforce (Local Government Employers 2018). Within the Finnish model of government, municipalities are fairly autonomous with respect to the central government, and most welfare services are produced at the local level (Kettunen 2006; Torres 2004). While unionization in Finland has decreased during the past 20 years, it is among the highest in the European Union (Eurofound 2015). Overall trade union membership in the country was 74 per cent in 2016. Trade union membership is especially high in the local government sector, where slightly less than 90 per cent of the employees belong to a union (Ministry of Economic Affairs and Employment 2017).

The public sector context forms a characteristic environment for HR practitioners. Knies et al. (2018) present some of its aspects which affect the work of 
HR practitioners. Firstly, there is the specific nature of organizational performance since public organizations have multiple, sometimes conflictual goals. Also, stakeholders such as politicians, trade unions and employer organizations have more influence on HR practices applied in public than in private organizations. For example, salaries and benefits are more often subject to collective bargaining. As another example, financial incentives are less commonplace in public than private settings. Lastly, 'red tape' can make altering established rules and practices difficult (Knies et al. 2018). In Finland, the status of HRM and the level of how strategic HRM is conducted in municipalities vary a great deal depending on the size of the municipal organization (Hakanen et al. 2019).

The context of municipal organizations provides a fruitful environment for this study. Finnish municipalities have eagerly adopted NPM ideology with a focus on professional leadership and profit responsibility as well as administrative reforms (Haveri 2006; Häikiö 2010). This has resulted in pressures stemming from local and national governments for organizational actors to adopt private sector practices and principles and hence become more business-oriented and consequently contribute to organizational performance. As distinct professional actors, HR practitioners in public organizations are targeted by these pressures (Bach \& Bordogna 2011; Bach \& Kessler 2007; Harris 2005; 2007; Truss 2008; Truss 2009; Truss 2013).

In the mid-1980s, many HRM reforms influenced by private sector managerial practices were adopted in the public sector, although these new personnel regimes were implemented quite slowly and ultimately gained a foothold during the 1990s (Pollitt \& Bouckaert 2004). Examples include introduction of performance-related pay, increased decentralized management and results-orientated steering. The transformations were, however, radically different from management in the conventional understanding of the Nordic welfare model, which for example stresses continuity in the planning of both employee relations and services (Christensen \& Lægreid 2002; Kettunen 2006). Internationally, many public organizations have gone through cutbacks and encountered increasing demands for accountability and improved service quality (Knies et al. 2018). In Finland, reforms in service provision such as outsourcing, privatizing and the purchaser-provider model are increasingly applied.

Furthermore, the Finnish municipal sector has encountered challenges in trying to meet the growing service needs of the ageing population, coupled with substantial retirements and relatively high unemployment rates, combined with a decreasing share of central government funding. In 2010, the sector was expected to confront recruitment problems and suffer from serious labour shortage since the estimate was that approximately half of the current municipal workforce would retire by 2025 (Association of Finnish Local and Regional Authorities 2010).

Finland has undergone extensive structural changes towards larger municipal entities during the past and current decade. Especially during the first decade of the 2000s, over 100 municipal mergers took place (Association of Finnish Local and Regional Authorities 2016). Reports analysing these processes have stated that they demand a high level of involvement and competence on the part 
of municipal HR practitioners and managers (Hakanen et al. 2019; Stenvall et al. 2007).

The economic recession started by the global financial crisis in 2008 further strengthened the NPM-induced demands for performance (Bach \& Bordogna 2013; Roche \& Teague 2012). In many European countries, the financial crisis was accompanied by austerity measures concerning public sector employment with staffing cuts targeted at managerial and administrative personnel in the public sector. Since there were fewer resources to invest in HRM, HR functions underwent considerable restructuring (Bach \& Bordogna 2013). In Finland as well, the financial crisis affected the municipal sector and led to cuts in staff expenditure. Previously anticipated increases in the recruitment of employees due to the service needs of the aging population were cancelled and instead new recommendations to decrease staffing costs were given. These included layoffs, limited recruitment policies and restructuring of work organization and content (Association of Finnish Local and Regional Authorities 2009).

The challenges facing HR practitioners in the municipalities during this study were therefore immense; the municipal sector needed to compete with private companies for the even smaller cohorts of young workers entering the labour market, retain current employees as long as possible before they retire, and operate in growing organizations with financial cutbacks and increasing demands for overall performance, productivity and service quality.

\subsection{High performance and well-being at work as institutional dis- courses in Finnish working life}

The demands for well-being at work and high performance are part of the context where HR practitioners position themselves professionally. Shared, culturally and historically situated discourses are influential and important resources for professionals when they construct their positions in organizations and society.

From hindsight, we can see that during the first decade of the 2000s, high performance and well-being at work developed into institutionalized working life discourses in Finland. Actors ranging from employer organizations, trade unions, media, central government, research funding, as well as academic and applied research contributed to an emphasis on well-being at work as an objective alongside productivity and overall performance (Anttonen \& Räsänen 2008; Kangasharju \& Pääkkönen 2010; Kivistö et al. 2014; Local Government Employers 2007a; 2007b; 2008; Vanhala et al. 2012; Väänänen \& Varje 2014).

\subsubsection{The discourse of high performance strengthens}

I approach the demands for performance as repetitive discursive acts employed by Finnish institutional agents during the first decade of the 200os. The highperformance discourse emphasizes multiple aspects of accomplishing something faster, cheaper or better. Concepts which are connected to performance include, for example, productivity, effectivity and quality. Moreover, high per- 
formance can be understood as an individual-level, team-level or organizational-level outcome. In the municipal sector, Local Government Employers (2008) defined performance as follows: 'High performance means a municipality's ability to organize services in a financially sound way regarding effectiveness, service quality, process flow and employee capability'.

The discourse of high performance is discernible especially through the governmental productivity programme implemented in the 2000s (Kangasharju \& Pääkkönen 2010) and in the demands imposed on municipal organizations for improved performance (Association of Finnish Local and Regional Authorities 2008; Local Government Employers 2008). The productivity programme included vast savings and guidelines for limiting new recruitments when personnel retired. Kangasharju and Pääkkönen (2010) point out that the productivity programme attracted considerable media attention and criticism of its negative effects on personnel in the public sector. At least partly due to this negative publicity, attention and resources were allocated to well-being at work. The demands imposed on municipalities were manifested particularly in recommendations to improve performance and productivity (Association of Finnish Local and Regional Authorities 2008; Local Government Employers 2008).

A central aspect of the high-performance discourse is that performance can and should be planned, measured, and controlled by management. Hence, it is very much in line with the adoption of NPM in the Nordic context (Christensen \& Lægreid 2007). Institutions like Local Government Employers have emphasized the role of HR practitioners and HR practices in this context. Here, HR practitioners are viewed as the actors who plan suitable HR practices (e.g. recruitment, competence development, work organization) in line with strategic plans of municipal organizations, and guide and influence line managers to implement them. In 2003, Local Government Employers together with the sector's trade unions stated how good HRM is the key to success in municipalities (Local Government Employers 2003), which echoed the strong research stream of HRM-performance at the time (Boselie et al. 2005; Huselid 1995).

\subsubsection{The discourse of well-being at work enters the picture}

Following the growing strength of the performance discourse during the beginning of the 2000s, well-being at work became more and more prominent on the agenda of Finnish institutions (Blom \& Hautaniemi 2009). Even though the concept of well-being was novel, state and labour-market organizations had discussed topics related to well-being at work for decades. Evolvement of how the concept of well-being at work was used in the 2000s is observable, for example, in the media (Väänänen \& Varje 2014) as well as in public policy (Kivistö et al. 2014). Well-being at work was adopted as a concept encompassing and sometimes replacing, for example, occupational safety and health, work environment, and work ability between 2000 and 2010 (Väänänen \& Varje 2014). For example, in 1994 and 1998, ministry committees published evaluations of the directions and central aspects of work environment research (Ministry of Employment and the Economy 1994; Ministry of Social affairs and Health 1998). In the middle of the following decade, a new committee was appointed to revise 
the previous evaluations. This time, however, the concept of work environment was replaced with well-being at work (Ministry of Social Affairs and Health 2005).

In the 200os, interest in well-being increasingly reflected intensified efforts to increase productivity and performance of individuals and organizations (Findlay et al. 2013; Sointu 2005; Väänänen et al. 2012). Behind these demands for productivity was, for example, the fact that, like in other Nordic countries, the number of senior workers in Finnish municipalities was growing (Lindström et al. 2008) as were the effects of NPM. Media, research and policy interest in the financial impacts of ill-being at work through for example absenteeism and early retirements spurred employers to implement diverse well-being programs and practices in work organizations.

Luoma and Viitala (2015) argue that the attention on well-being and ill-being in working life increased in Finnish HRM already in the turn of the millennium. This was a backlash to the then extensive focus on performance management which dominated in the 1990 s and the beginning of the 2000s. Furthermore, the authors argue that the interest in well-being in Finland mirrors the strong values of the welfare society. Even though Finnish HRM has been strongly influenced by international management trends, focus on well-being at work was more a Nordic phenomenon (Luoma \& Viitala 2015, 38). This well-being discourse emphasized needs to increase the age of retirement and, for example, work engagement, as well as decrease burnout, stress, and sick leaves among employees. There was an increasing awareness of the financial impact of these phenomena on work organizations and society. Hence, well-being was strongly coupled with performance.

For example, employer organizations and trade unions brought forward the phenomena of well-being at work and performance side by side. The Productivity Round Table was a cooperation body founded in 2007 by the central labour market organizations together with research and development funders: the Finnish Funding Agency for Technology and Innovation and the Finnish Work Environment Fund. Also, the Finnish Institute of Occupational Health (FIOH) and the Center for Occupational Safety were among the founders. The body's official aim was to promote productivity, quality of work life and cooperation in Finland. In their activities they, for example, organized seminars, published information and highlighted successful workplaces which had developed well-being of employees and organizational productivity side by side (Productivity Round Table 2011).

In 2008, FIOH - a research institute working under the Ministry of Social Affairs and Health - coordinated an EU program which produced a new and influential definition of well-being at work: 'Well-being at work means safe, healthy, and productive work in a well-led organization by competent workers and work communities who find their job meaningful and rewarding and see work as a factor that supports their life management' (Anttonen \& Räsänen 2008, 28). Here as well, we can observe the link to performance, this time in the form of productivity. The definition is still in use (Finnish Institute of Occupational Health 2019). 
Another institutional example is how research and development funding were targeted at studies investigating these phenomena during the shift between 2000 and 2010. The Academy of Finland had its WORK-research programme during 2008-2011 where the objective was to increase understanding about the relationship between work and well-being (Academy of Finland 2018; Pietikäinen 2011). The Finnish Work Environment Fund, backed up by the Productivity Round Table, financed its own research programme to increase both productivity and the quality of working life in 2009-2014 (Productivity Round Table 2011). Examples from the municipal sector show that Local Government Employers around the time of founding the Productivity Round Table published their recommendations on HRM, well-being at work and performance in local government in which the concepts were intertwined and where HRM was presented as the managerial activity enabling the two (Local Government Employers 2007a, 2007b; 2008). 


\section{Methodology}

In this chapter, I present the methodological choices of the thesis. I start by stating my position on the philosophy of science, which has guided my ontological and epistemological thinking. Then I present the empirical materials and their collection. Next, I move on to discuss the discourse analytical approach used in the studies. The section ends with contemplation of my own role as a researcher as well as ethical questions that arose during the research process.

\subsection{Moderate social constructionism}

The way I have formulated research questions, made methodological choices, and argued for results are shaped by my epistemological and ontological standpoint. Ontology can be understood as our understanding of what reality is while epistemology refers to our knowledge of reality, for example, how we can determine that a belief of reality is true or whether our research results are a legitimate piece of scientific knowledge (Johnson \& Duberley 2000). Questions regarding ontology, epistemology and methodology constitute research paradigms. In other words, research paradigms are sets of common beliefs among scientists about how science is understood and practiced (Kuhn 1962).

There is a wide divide in social sciences between positivist and interpretivist research. Positivism assumes that there is objective and unbiased information of the world that is possible to observe and measure. Interpretivism takes a contrary standpoint and sees the way we perceive the world as laden with values. The knowledge we obtain of the world is filtered through interpretation. As a part of the interpretivist framework, this study joins the paradigm of social constructionism in understanding the knowledge we may obtain of social reality.

According to social constructionism, reality and knowledge are created, altered or reinforced through our interpretations (Berger \& Luckmann 1967; Searle 1995). Furthermore, a social constructionist perspective is critical to taken-for-granted assumptions and objective truths. Our social reality - consisting of historical developments and cultural conventions - is what guides us in our understanding of the world. Moreover, the constitutive character of language use can be found in the core of social constructionism. This means that how we use language in social situations has for instance implications for the formulation of social norms and power relations (Burr 2003). Since I am inter- 
ested in how HR practitioners use language to position themselves professionally, social constructionism is a workable philosophical standpoint for me. However, like most strands of philosophy, social constructionism has also been the topic of considerable debate.

Especially the postmodern stream of social constructionism has been criticized for its anti-foundational stance; this means the complete denial of an objective reality that exists apart from our interpretations (Baert et al. 2014). Also, the relationship between social constructionism and realism in discourse analysis has caused considerable debate (Grant et al. 2009). In addition, the rejection of causal explanations by the postmodern version of social constructionism is considered problematic. Through its anti-causal stance, it is limited in explaining wider societal phenomena (Baert et al. 2014; Reed 2009).

Fairclough (2005) criticizes the adoption of extreme versions of social constructionism in discursive research within organization studies. By this he means that there has been a tendency to reject the structural character of organizations and focus solely on organizations as accomplishments of discourse. By structural character he refers for example to institutional arrangements and organizational structures. This can be explained by a tendency of social constructionist researchers to take steps as far away as possible from positivist research. Many researchers fear that accepting structures in organizations is somehow strongly attached to positivism and the only way out is to reject realism as well (Fairclough 2005). Reed (2004), another discourse analyst and critical realist, acknowledges that extreme constructionism in postmodern discourse analysis undermines organizational structures as influencing factors in organizations. In this sense, much of discursive research is anti-realist in its ontology and epistemology (Reed 2004).

Fairclough (2005) argues for a critical realist ontology as the basis for discursive studies in organizations and management research. We should not focus simply on discourses when studying organizations but recognize that there is also a material dimension (mainly structures) to reality. The epistemology of Fairclough is therefore dualist: to gain knowledge of reality we should focus both on discursive agency and non-discursive structure. Explicitly, he argues for the following:

a critical realist position which is moderately socially constructivist but rejects the tendency for the study of organization to be reduced to the study of discourse, locating the analysis of discourse instead within an analytically dualist epistemology which gives primacy to researching relations between agency (process, and events) and structure on the basis of a realist social ontology (Fairclough 2005, 916).

Fairclough (2005) sees the social world as transformational: agents are influenced by social structures and reproduce and transform them at the same time.

My own understanding of social constructionism has developed during the process of working on this thesis, considering the relationships between different actors in society, and acquiring knowledge on the philosophy of science. As a result, my position follows a moderate version of social constructionism which 
follows Fairclough's (2005) reasoning to some extent. However, while he labels himself a critical realist, I prefer to position myself as a moderate social constructionist. I concur with the strong role of language in understanding reality and obtaining knowledge of it. It is, however, possible to acknowledge language use in relation to what Fairclough terms structural elements in society. Examples of these structural elements in this thesis include the age structure of the population, the municipal decision-making mechanism and the publication of political programmes. While it is a question of discursive analysis how age is portrayed, how decisions are made, and what political programs include, these examples can also be interpreted as structural elements which make it possible to 'anchor' the analysis instead of the ongoing interpretative cycles in extreme versions of social constructionism.

\subsection{Discursive approach}

Interest in the use of language strengthened during the 1990s in all social sciences. As a part of this 'linguistic turn,' discourse analysis became an established research approach in organization and management research during the first decade of the 2000s (Alvesson \& Kärreman 2000; Fairclough 2003).

Discourse analysis as a research approach has several varieties, and there are a wide array of different definitions and key characteristics available (Alvesson \& Kärreman 2000; Grant et al. 2009). Within organization and management research, some common understandings can nevertheless be identified. Discourses are viewed as interrelated texts and practices (expressions or other ways of language use) around these texts. Furthermore, discourses are influential in constructing how we understand reality (Grant et al. 2009). In this thesis, I follow Fairclough's $(2003,124)$ definition of discourses as recurrent ways of language use that have common characteristics and that provide meaning to our social environment and represent it. To further clarify my approach to discourse analysis, I elaborate on two dimensions: the constitutive strength and formative range of discourse (Alvesson \& Kärreman 2000).

By constitutive strength, Alvesson \& Kärreman (2000) refer to how strong or muscular discourses are in shaping reality. Are discourses simply media for social interaction, conversations, in analytically distinct situations or are they coupled with other levels of social reality besides the situation at hand? Here, my perspective is located approximately half way between the two extremes. Discourses have a rather muscular role in shaping professional positions. In line with social constructionism, I see discourses as influential phenomena with a socially constructive character. Despite the strength of discourse, professionals are not helpless victims of discursive forces. As I discussed in section 2.1.1 (Understanding professional positioning as an active process), although professionals are affected by discourses which ascribe them certain positions, they also adapt and tweak their positions through varying identifications (Törrönen 2001). 
The other dimension of discourse which requires elaboration is formative range. Formative range implies that discourses occur on different levels in society. From a close-range perspective, discourses are local and situated conversations which for example occur between colleagues over a cup of coffee or in a WhatsApp message sent to a family member. From a long-range or macro perspective, discourses are historically situated, rather universal and standardized ways of referring to a phenomenon (Alvesson \& Kärreman 2000). Current macro or even mega-level examples include discourses of digitalization and globalization. The vocabulary used to describe these macro- or mega-level discourses in research varies. For example, Kuhn (2009) uses the terms discursive frame, cultural logic and institutionalized discourse to describe the phenomena of managerialism and legal professionalism in a single article. Zanoni and Janssens (2004), on the other hand, call the societal interest in diversity a grand discourse.

Since the societal and organizational interest in the phenomena of well-being at work and high performance are crucial in this study, I need to decide on a sufficiently accurate and understandable terminology to describe them. For two reasons, I decide to refer to them as institutionalized discourses. Firstly, I understand these phenomena as strongly coupled with established institutions such as central-government and labour-market organizations. Hence, the term 'institutional' is appropriate for my aims. Secondly, since my interest is in language use, the term 'discourse' is a better alternative than, for example, 'institutional demand', 'institutional activity' or 'institutional logic'.

My own approach to this formative range of discourse is, again, situated between the two extremes of micro and macro. My interest is to address both levels. I take a meso-discourse approach which means that I am sensitive to language use in a particular context (in my case during research interviews) but all the while I try to find broader patterns in the use of language, which I interpret as signs of more macro-discursive phenomena. This combination of different levels of analysis is elaborated in section 4.4 (Doing analysis).

\subsection{Collecting empirical materials}

The empirical materials of this thesis consist of semi-structured research interviews which were conducted with HR managers in municipal organizations between 2005 and 2010. There are several reasons for choosing to do interviews as a method of collecting empirical materials in this thesis. Alvesson and Deetz (2000) and Kuhn (2009) point out that qualitative research interviews are a workable method if the interest is in locating discursive resources used by people in specific situations as well as grander discourses which shape their positions. Also previous studies (Daudigeos 2013; Zanoni and Janssens 2004) have employed interviews as data when the aim has been to understand the work of organizational professionals.

The interviews were collected in two research projects lead by Professor Sinikka Vanhala at Helsinki School of Economics, which merged in 2010 with two 
other schools and became the Aalto University School of Business. These projects were 1) Subproject of the Regional HR-strategy Initiative (Henstra) 20052009 and 2) HRM, Employee Well-being and High Performance of Companies (Hiperco) 2009-2012 (Vanhala et al. 2012). During the second project, in 2010, I conducted the research interviews and collected the materials for studies two and three, while another project researcher working for the Henstra project conducted the interviews for the first study. The materials are summarized in Table 1 below.

Table 1. Empirical materials.

\begin{tabular}{|c|c|c|c|}
\hline Empirical materials & Collection & Utilization & Discussed themes \\
\hline $\begin{array}{l}\text { Semi-structured inter- } \\
\text { views with } 9 \text { municipal } \\
\text { HR managers }\end{array}$ & $\begin{array}{l}\text { Collected } \\
\text { in } 2005- \\
2007\end{array}$ & $\begin{array}{l}\text { Empirical materials } \\
\text { for the first study } \\
\text { (Lindström \& Vanhala } \\
\text { 2011) }\end{array}$ & $\begin{array}{ll}\text { - } & \text { Strategy and HR work } \\
\text { - } & \text { HR practices } \\
\text { - } & \text { HR organization }\end{array}$ \\
\hline $\begin{array}{l}\text { Semi-structured inter- } \\
\text { views with } 10 \text { municipal } \\
\text { HR managers }\end{array}$ & $\begin{array}{l}\text { Collected } \\
\text { in } 2010\end{array}$ & $\begin{array}{l}\text { Empirical materials } \\
\text { for the second and } \\
\text { third studies } \\
\text { (Lindström \& Vanhala } \\
\text { 2013; Lindström } \\
\text { 2016) }\end{array}$ & $\begin{array}{ll}- & \text { HR organization } \\
\text { - } & \text { Performance and HR } \\
& \text { work } \\
\text { - } & \text { Well-being at work and } \\
& \text { HR work }\end{array}$ \\
\hline
\end{tabular}

Interviewees were invited to take part in the studies if the municipality they were employed by was large enough to have a separate HR unit and a person appointed as HR manager. Consequently, they worked as HR managers in both large city organizations (over 100,000 residents and over 10,000 employees) and medium-sized municipalities (30,000-100,000 residents and 2000-4000 employees).

During the interviews, the questions asked were predominantly open-ended, except for those about background such as age and tenure. We discussed broad themes chosen together with the research group, based on our research interest and previous studies. All interviewees were contacted and invited to participate personally via e-mail and phone. We were open about the aim of the interviews and the projects behind them in all communications. The fact that no one declined to participate is an indicator of the practical relevance of the studies. The discussions did not touch upon matters traditionally considered sensitive such as health, family or sexuality. Instead, the interviewees were firmly in their professional and expert roles during the discussions.

All interviews were semi-structured, which means that some of the themes of discussion were decided in advance based on previous research and our research interest while the order of the discussed themes varied. The interviewees were also encouraged to bring their own themes into the discussion.

The interviews were recorded and later transcribed verbatim. All transcripts have been analysed, stored and handled in a way that protects the anonymity of the interviewees and the organizations they represent. These transcripts allowed me to go back to the situations of the interviews and pay attention to as- 
pects of the interaction otherwise difficult to grasp during the interview situation such as choices of words. All materials are in Finnish. Chosen excerpts from the materials were translated to English to exemplify central findings in the three articles. Also, interview excerpts were rewritten in standard language to protect the anonymity of the interviewees.

Interviews are social situations co-constructed by the interviewer and the interviewee (Alvesson 2003). This means that they are far from objective forms of harvesting information. Instead, the topics brought up and the interaction between us as discussants had an impact on them. These situations were considered when doing analysis, which I elaborate in the following section.

\subsection{Doing analysis}

Analysing the empirical materials was a long and fruitful process during which the research questions I had in the beginning of my $\mathrm{PhD}$ project evolved towards the final ones presented in this thesis. In the analyses I draw upon discursive approaches, namely, critical discourse analysis (CDA) (Fairclough 2003; Wodak \& Meyer 2009) and discursive legitimation (Van Leeuwen 2008; Van Leeuwen \& Wodak 1999). The analyses were accompanied by regular discussions about the phases and interpretations between me, my supervisor and other members of the research teams.

Discourse analysis is a flexible framework. The guiding principles allow it to be applied on various questions and contexts and through a variety of methods (Chouliaraki \& Fairclough 2010). Within organization and management research, some common understandings can nonetheless be identified. Discourses are viewed as interrelated texts and practices around these texts. They are influential in constructing our reality, and consequently, they determine social practices (Grant et al. 2009).

Some general principles were followed in the analyses of all three studies. Firstly, I adhere to Fairclough's (1995; 2003) approach of simultaneous analysis on three different levels: text, discursive practice, and social practice. Texts in my case consist of the transcribed interviews. To analyse them as discursive practices means to consider the ways the texts were produced and interpreted. The genre of the research interview includes conventions which may affect how phenomena are described and how certain topics are emphasized. Lastly, the dimension of social practices refers to taking into account the social and institutional settings of the materials, and especially, the power relations of the actors involved in their creation (Fairclough 2003). The analyst should move back and forth between these levels. Briefly, my analytical aim was to attend to both the broad and the local. In the following, I discuss my decisions for what these principles have meant for the analysis in each of the studies separately and describe the processes of analysis.

In the first study (Lindström \& Vanhala 2011), we identified discourses as social constructions which, described by Dick (2004), were at least partially presented as natural or self-evident of the social domain under research. This was 
accomplished by rereading the texts and open categorizing. Viewpoints and discussions, which were both repeated and emphasized, were interpreted as discursive texts and parts of a larger discursive whole. The research question was 'How do HR managers discursively construct the roles of the HR function in local government organizations?'. Compared with the other two studies of this thesis, the perspective of power in positioning oneself towards others was most explicit. As we paid attention to how the discourses constitute and sustain underlying power relations (Fairclough 2003), we analysed what types of roles these discourses assert for the HR function in relation to municipal line and top management. Moreover, we discussed the relationships between the discourses identified and strived to give some explanations for the similarities and discrepancies between them.

We continued to use Fairclough's approach (2003) in the second study (Lindström \& Vanhala 2013) in which we asked: 'How do HR practitioners discursively construct performance in local government HRM?' In the process of analysis, we scrutinized the textual materials related to performance in the interviews with municipal HR managers and identified three predominant discourses. We analysed both the relationships between these discourses and their relationships with the surrounding local government context. Following the common characteristics of discourse analysis, we did not concentrate on single responses or interviewees; instead, our focus was on the textual material as a whole. For an overview, we categorized the texts according to the patterns recognized in them. We searched for commonalities, often-repeated features, and differences in the texts. These common perspectives were interpreted as discourses and further developed to generate an analysis of the phenomenon. We also analysed and discussed the potential reasons for the discourses identified in the local government context.

In the analysis employed in the third study (Lindström 2016), I identified how the position of HR is legitimated by drawing upon the desirability and appropriateness of well-being as a topical value of work life in the Finnish municipal context. Here I employed the analysis of discursive legitimation (Van Leeuwen 2008; Van Leeuwen \& Wodak 1999). My research question in this study was as follows: 'How do HR managers in municipal organizations discursively legitimate their position through the discourse of well-being at work?'. As a result, I identified four discursive themes connected to well-being at work which require and justify the position of HR practitioners in management programmes, practices and resources. The analysis was accomplished by examining the patterns and repeated conceptions that the interviewees linked to well-being at work. These patterns were traceable in several parts of the interviews, and they were identified as discursive themes. Third, I analysed how the interviewees expressed - discursively legitimated - their own position in relation to these themes (Goodrick \& Reay 2010; Van Leeuwen 2008) and scrutinized how they constructed meanings of well-being at work in municipal organizations and society (Fairclough 2003). Again, I searched for modes of expression that could be distinguished in multiple parts of the textual whole. 
In the third study (Lindström 2016), I used research software (Atlas.ti) in the early stages of analysis when categorizing and managing pieces of text. Here the use of research software in managing empirical materials has not made the processes of analysis different to that of the first and second studies, where I used Microsoft Word and Excel in data management. It has simply meant using different tools in the process (Jolanki \& Karhunen 2010).

\subsection{Positioning myself as a researcher}

In line with the constructionist view on how knowledge is produced, it is essential to consider my own position in the research process. During the interaction with interviewees, from initial contacting to the interview situations themselves, my choices of words and the way I have formulated questions have affected the content of the discussions. This researcher influence is important to consider when analysing interview responses (Alvesson 2003; Tiittula \& Ruusuvuori 2009). For example, in the interviews collected in 2010, I explicitly asked about how they understand performance and well-being in their own work context. By doing this, I provided them with the central concepts of the thesis right from the start.

Furthermore, an analysis guided by a discursive approach calls for acknowledging all the ways the texts are produced. This means that I have carefully analysed the situations of the interviews. The research interview includes conventions which may affect how the interviewees describe and emphasize the phenomena. Consequently, the interview texts used as data are co-created (Alvesson 2003).

Grant et al. (2009, 215) highlight the reflexivity of the research process when conducting discourse analytical studies. Simultaneously, discourses are 'ontological performances of meaning making'; this means that they are part of constructing the social world. Also, they are seen as the researcher's epistemological representations of meaning. Consequently, it has to be acknowledged that the researcher's own analysis is a social construct depending on her explicit or implicit choices during the research process. I have been sensitive to my own role by analysing the situations as they 'appear' in the interview transcripts for example by paying attention to which one of us - researcher or interviewee brought up a specific theme to discuss. In the interpretative part I consider my own background as a scholar and reflect on my views as openly as possible. I also acknowledge that my master's education in social sciences, which included studies of public administration, and previous work experience in the municipal sector, spurred my interest in this research context. A couple of years before starting my career as a researcher and my doctoral studies, I worked with planning and coordinating topical seminars and courses for a wide range of municipal professionals. This shared experience provided me and the interviewees with a 'common language' of sorts when discussing matters of municipal organization and management.

Tiittula and Ruusuvuori (2009) point out that our conceptions of reality are reflected upon the phenomena under study for example through the termino- 
logy choices we make in the discussion. My doctoral studies have been conducted part-time. Before and during my doctoral studies, I was employed as a researcher at Aalto University and FIOH. Here, I have been involved with questions around well-being at work, high performance and the work of HR practitioners. These experiences have inevitably affected me in my choices and interpretations. Being employed by organizations which are strongly involved in research on working life and organizational development has made me both more familiar with the institutional environment of the work of HR practitioners and more aware of the institutionalized discourses concerning working life in general. In my working environment, I am influenced by and construct them myself.

My career in research started in 2009 when I was employed as a project researcher at Helsinki School of Economics (later Aalto University School of Business) in a project called 'HRM, employee well-being and high performance of companies (Hiperco)' financed by the Academy of Finland's WORK-research program (Vanhala et al. 2012). In a follow-up project, 'Hyvinvointia ja tuloksellisuutta hyvällä henkilöstöjohtamisella' ['Well-being and performance through good human resource management'] (Hyöty)', we continued studying the same themes (Vanhala 2013). This project was financed by the Finnish Work Environment Fund which is a research funding body owned by employer organizations and trade unions, and part of the 'Palje' research programme (Productivity Round Table 2011). Furthermore, I changed my employer from Aalto University to FIOH when the Hyöty project began and I am still employed there. Consequently, this thesis journey is strongly tied to the context it aims to study.

My own ties to both research funders and employers during the research process have made my thesis work possible. However, I have not experienced any pressure by either funders or employers which might have affected the research process in any other way than providing me with timely constraints for conducting the work. 



\section{Three studies on the professional positioning of HR practitioners in municipal organizations}

In this thesis, I examine the professional positioning of municipal HR practitioners. I especially study how they use discourse in the process. Next, I present the three studies, their results and contributions. Particularly, my aim is to discuss their contributions from the viewpoint of the overall aim of the thesis: how do they shed light on the positioning of HR practitioners in municipalities?

\subsection{Divergence in HR functional roles in local government} (Study 1)

Lindström, S. \& Vanhala, S. (2011). Divergence in HR functional roles in local government. Public Management Review, 13(7), 1023-1040.

This study is about the positions of HR practitioners in Finnish municipalities and how their self-positioning is accomplished. As a starting point, we sketch out how the public sector HR function - the specialized unit focusing on human resource management - has not received as much research attention from scholars as its private sector counterpart (Brown 2004; Gould-Williams 2007; Knies al. 2018). Moreover, we explain the particularities of public sector organizations and management ranging from its diverse stakeholders to increased pressures for performance.

The study suggests that the positions discursively constructed by municipal HR practitioners entail both contradictory elements and variations in power between the HR function and other actors in the organizations. As a result, we locate five predominant, meso-level discourses which HR practitioners use in the process of discursively constructing their position: control, HR-advocate, strategic-partner, defence and political-reliance. The control discourse and the HR-advocate discourse are constructed towards the line management level in municipalities. In the control discourse, production of assessments and reports on the implementation of planned HR practices is an important feature of their work. They portray line managers as sometimes ignorant of or uninterested in 'correct ways of doing HRM'. The HR-advocate discourse stresses another side of their relationship with line managers. Here, their position is proactive and 
that of an eager spokesperson for HRM while they spar and support line managers.

Then again, the strategic partner discourse and the defence discourse are aimed at top municipal management. In the strategic partner discourse, HR practitioners are in a position where they work alongside municipal top managers and emphasize how the work is 'done together'. Conversely, in the defence discourse, they bring forward how the commitment of top management is crucial to their work because they still lack the same authority as top managers possess. The last discourse, political reliance, reaches outside the immediate organization, and constructs their position as reliant on municipal electees, whose seal of approval is needed for HR work.

How does this study contribute to understanding the professional positioning of municipal HR practitioners?

This study contributes to the overall aim of the thesis by identifying two principal ways of how positions of HR practitioners are constructed. First, the way actors talk about and refer to others is a key part of constructing their own positioning (Ybema et al. 2009). In this study, HR practitioners portray their own stance by talking about how they operate towards line managers, top managers and elected policymakers. Particularly, they employ the discursive strategies of controlling and advocating HRM towards line managers. The position towards top managers is constructed by using the strategies of strategic partnering and defending. Finally, they also construct their position towards elected policymakers through the discursive strategy of political reliance.

Second, in this process they employ discursive resources ranging from both traditional public sector ideals and demands which can be traced back to the institutional discourse of performance. To clarify, I suggest that the defence discourse and the political-reliance discourse both reflect traditional public sector ideals of continuity and hierarchy in administration. In contrast, the proactivity, control and strategic partnership emphasized in the other discourses mirror norms congruent with the institutional discourse of performance.

Finally, the explicit observation of the political reliance discourse contributes to previous research on HR roles by bringing out the relationship between HR practitioners and local-level policymakers, which is a specific characteristic of the work of public sector HR practitioners.

\subsection{Performance in local government HRM: The role of external customers (Study 2)}

Lindström, S. \& Vanhala, S. (2013). Performance in local government HRM: The role of external customers. Baltic Journal of Management, 8(3), 252-268.

In the second study, we focus on performance in municipal HRM. As a background, we discuss the centrality of the concept of performance because of its prominence in both the HRM research field and as the institutionalized dis- 
course of performance in Finnish society. However, performance has so far primarily been studied through statistical methods trying to show causality between HRM and performance outcomes. In order to provide new insights on the phenomenon, we follow Janssens and Steyaert's (2009) calls for a focus on language in relation to it. Hence, in this study we focus on how the talk of HR practitioners produces and shapes performance in municipal HRM.

Moreover, previous studies have largely ignored the societal context of HRM by focusing solely on internal stakeholders (Ferrary 2008; Guerci \& Shani 2013; Janssens \& Steyaert 2009; Paauwe 2009). In public settings, the dimensions of performance are more varied due to the multitude of different stakeholders (Pollitt \& Bouckaert 2004; Walker \& Boyne 2009). Consequently, by analysing performance in the context of public sector HRM, we are able to study the phenomena of performance from a wider perspective than in the bulk of previous research, which is situated in the private sector. Our research question in the article is the following: How do HR practitioners discursively construct performance in local government HRM?

Through the analysis of the performance talk of HR practitioners, we show that performance in local government HRM is constructed in three ways. First, we identify performance as a service in the talk of HR practitioners. Here, performance means taking care of the skills and well-being of employees who provide municipal services in, for example, healthcare or teaching. Through a competent and well-being workforce they can, in the end, meet the needs of local residents. Second, performance is about developing work processes in order to make savings and increase efficiency. Also, performance is portrayed here as something manageable and controllable by HR practitioners. The third way of constructing performance is by highlighting the changes it offers to HR practitioners themselves. Demands for higher performance originating both inside and outside the organizations are the source of both opportunities and threats. As an opportunity, the focus on performance allows HR practitioners to 'get back to the roots' of municipal work: to keep the customer in focus. Simultaneously, they construct their position as strategically important actors. As a threat, performance in municipal work is far from simple and the increasing demands for performance are a source of confusion and insecurity among them.

How does this study contribute to understanding the professional positioning of municipal HR practitioners?

While this is not a study explicitly focusing on professional positioning, the centrality of external customers in the findings suggests that HR practitioners identify and use local residents as relevant actors in their own positioning. In this way, the study shows another overlooked aspect in the position of HR practitioners by bringing in local residents.

Furthermore, the findings suggest that the extensive emphasis which HR practitioners put on services, process development and customer orientation mirror the institutionalized discourse of performance. While repeating and reflecting institutionalized demands for performance in their talk, they construct 
their own position as a carrier of these valued and sought-after attributes. Moreover, HR practitioners adapt the institutionalized discourse of performance by framing it as an opportunity for them as a professional group to 'get back to the roots' of municipal work; focusing on the needs of local residents is what makes their position strategically important.

However, this study shows that the positions constructed by HR practitioners are not free from ambiguity. They are portrayed both as competent managers in control of performance and as confused and insecure when facing new kinds of demands for increased customer-orientation.

\subsection{Legitimating the professional position of HR through well-be- ing at work (Study 3)}

Lindström, S. (2016). 'An army of our own.' Legitimating the professional position of HR through well-being at work. Scandinavian Journal of Management, 32(4), 189-196.

This study is about how HR practitioners employ the discourse of well-being at work in relation to their professional position in municipalities. As a starting point, I identified the desirability and appropriateness of well-being at work as a value of working life in Finnish municipalities. During the time of the study, well-being at work was a societal-level, institutionalized discourse pumped up by policymakers, employer organizations and trade unions in Finland.

Well-being at work is perceived as a bone of contention in previous research on HR positions (Keegan \& Francis 2010; Renwick 2003). From perceiving well-being or more broadly quality of work life as the backbone of HR work (Jacoby 2004) to perceiving the employee perspective and, thus, well-being, as uninteresting (Kochan 2004), well-being has played a very shifting role in the positioning of HR practitioners. In this study, I apply the perspective of discursive legitimation to analyse interviews with HR practitioners in order to dig deeper into how the positioning of HR practitioners is accomplished. The research question in this study is as follows: 'How do HR practitioners in municipal organizations legitimate their position through the discourse of well-being at work?'

This study shows that HR practitioners in Finnish municipalities have embraced the discourse of well-being at work. As a result, I identified four discursive themes connected to well-being at work which HR practitioners employ to legitimate their professional position.

In the first theme, HR practitioners construct their position as 'managers and coordinators of structures' concerning well-being at work. Structures in this case refer to diverse programmes, projects and practices aimed to support and enhance the well-being of employees. In the second theme, they frame themselves as 'providers of individual opportunities,' which entails their ability to tailor work tasks, hours, locations and also to offer a number of different sports for employees to choose from. Simultaneously as HR practitioners construct 
themselves as the opportunity providers, employees are represented as responsible for 'taking' the opportunities provided. Third, I identify their position as an 'upholder of the agenda of well-being at work' with which they remind and bring forth the importance well-being plays in individual and organizational performance. And finally, HR practitioners position themselves as 'reminders of the meaningfulness of municipal work.' Here, they interpret meaningfulness in a goal-oriented way as work with clear objectives and the ability to see the results of one's work.

HR practitioners employ a wide range of different discursive strategies in the process. In normalization, they rename previously established HR practices as well-being at work practices. They also naturalize their past, which means that their new position as 'managers of well-being' is supported by their previous (and current) practices, for example, as an administrator and analyst of employee data. Rationalization is a strategy which they use to present their efforts concerning well-being at work as something of instrumental value to the municipality. Furthermore, they used moralization, which means that they draw upon the strengthened Western values of individualism and meaningfulness in representing what they can provide to well-being at work. Also, they connect with the institutional environment, which means they talk about the impact their work has on the functioning of the entire municipality. And finally, they refer to authorities such as national and municipal policy aiming for longer careers as well as research which supports their agenda.

How does this study contribute to understanding the professional positioning of municipal HR practitioners?

This study points out the importance of the institutional environment in the professional positioning of HR practitioners. HR practitioners draw strongly on the institutionalized discourse of well-being at work when talking about their own responsibilities and the importance of their work. Also, HR practitioners couple the discourse of well-being at work to their municipal environment by drawing upon traditional municipal norms of specialization and formalization as well as the ongoing demands of performance.

Furthermore, I add a contribution to the discussion on how well-being at work is perceived in connection to the work of HR practitioners. While several studies show the diminished interest of HR practitioners in well-being at work, I suggest more elaborate conclusions. In this study, well-being at work is strongly portrayed as a sought-after element of HR work. However, the strength of the performance discourse appears to 'override' well-being. The instrumental sense of well-being is emphasized at the expense of its inherent value.

In addition, the study provides an empirical study of HR positioning from the perspective of discursive legitimation. Discursive legitimation as a theoretical lens has so far not been applied in research on HR roles. In the study, I show how HR practitioners legitimate their position by bringing forth themes of wellbeing at work through a combination of discursive strategies. These discursive legitimation strategies can be traced back to previously theorized legitimation of practices (Van Leeuwen 2008) and the legitimation of professional roles 
Three studies on the professional positioning of HR practitioners in municipal organizations

(Goodrick \& Reay 2010). As a specific contribution to the study of professional positioning, I provide an example of how these strategies are intertwined. 


\section{Discussion and conclusions}

In this final chapter, I present the theoretical contributions of this thesis, followed by practical implications for HR practitioners themselves and policymakers. The chapter ends with an assessment of the main limitations of the thesis and some suggestions for future research.

Throughout this thesis, my aim has been to enhance our understanding of how HR practitioners position themselves in a municipal context. To keep the course towards this aim, my main, overarching research question in this thesis was the following: How do HR practitioners use discourses to strengthen their position in municipal organizations?' In answering this question, I have combined two theoretical perspectives: literature on professional positioning and literature on HR roles.

Three studies shed light on the positioning of HR practitioners in municipalities. Each of them answers the main research question from slightly different angles. In all the studies, I show how the positioning of HR practitioners reflects and employs the institutionalized discourse of performance. The first and second studies (Lindström \& Vanhala 2011; Lindström \& Vanhala 2013) show how the positioning of HR practitioners is aimed towards other actors in municipal organizations. The question regarding how the positioning of HR practitioners reflects and employs the institutionalized discourse of well-being at work is answered in the third study (Lindström 2016).

To summarize the results presented in the previous chapter, I argue that Finnish municipal HR practitioners strengthen their professional position discursively by using two dominant strategies: relational positioning and contextual positioning. In relational positioning they mirror and employ their relationships to other actors in municipal organizations, while in contextual positioning they mirror and employ the discourses of high performance and well-being at work used in institutional-level Finnish working life, which are linked to certain valuable competences. HR practitioners are able to employ both the institutional discourses of performance and well-being at work as opportunities to portray themselves as crucial professionals in the municipal environment, thus strengthening their professional position discursively. The results are summarized in Table 2. 
Table 2. Summary of results

\begin{tabular}{|c|c|c|c|}
\hline \multicolumn{2}{|c|}{$\begin{array}{l}\text { How do HR practitioners use dis- } \\
\text { courses to strengthen their posi- } \\
\text { tion in municipal organization? }\end{array}$} & Positions constructed & $\begin{array}{l}\text { Dominant discursive } \\
\text { strategies for strengthen- } \\
\text { ing their position }\end{array}$ \\
\hline Study 1 & $\begin{array}{l}\text { Portraying their work in } \\
\text { relation to other munic- } \\
\text { ipal actors }\end{array}$ & $\begin{array}{ll}\text { - } & \text { Watchdog } \\
\text { - } & \text { HR advocate } \\
\text { - } & \text { Strategic partner } \\
\text { - } & \text { Dependent on top } \\
& \text { management } \\
\text { - } & \text { Object of control }\end{array}$ & $\begin{array}{l}\text { Relational positioning } \\
\text { - } \quad \text { Line managers } \\
\text { - } \quad \text { Top managers } \\
\text { - } \quad \text { Policymakers } \\
\text { Contextual positioning } \\
\text { - } \quad \text { Institutionalized dis- } \\
\quad \text { course of high perfor- } \\
\quad \text { mance }\end{array}$ \\
\hline Study 2 & $\begin{array}{l}\text { Portraying their work } \\
\text { in relation to other mu- } \\
\text { nicipal actors } \\
\text { Rationalizing their } \\
\text { work in response to } \\
\text { municipal demands for } \\
\text { performance }\end{array}$ & $\begin{array}{ll}\text { - } & \text { Service provider } \\
\text { - } & \text { Work process deve- } \\
\text { loper } \\
\text { - } \quad \text { Customer oriented } \\
\text { change-maker }\end{array}$ & $\begin{array}{l}\text { Relational positioning } \\
\text { - } \quad \text { Local residents } \\
\text { - Employees } \\
\text { Contextual positioning } \\
\text { - Institutionalized dis- } \\
\quad \text { course of high perfor- } \\
\text { mance }\end{array}$ \\
\hline Study 3 & $\begin{array}{l}\text { - } \quad \text { Normalizing new prac- } \\
\text { tices } \\
\text { - } \quad \text { Naturalizing the past } \\
\text { Rationalizing their } \\
\text { work in response to } \\
\text { municipal demands for } \\
\text { performance } \\
\text { - Moralizing by drawing } \\
\text { upon values of individ- } \\
\text { ualism and meaning- } \\
\text { fulness } \\
\text { - Connecting with the } \\
\text { municipal environment } \\
\text { Authorizing through } \\
\text { policy and research }\end{array}$ & $\begin{array}{ll}\text { - } & \text { Manager and coordi- } \\
\text { nator of structures } \\
\text { - } \quad \text { Provider of individual } \\
\text { opportunities } \\
\text { - } \quad \text { Upholder of well-be- } \\
\text { ing at work agenda } \\
\text { - } \quad \begin{array}{l}\text { Reminder of mean- } \\
\text { ingfulness of munici- } \\
\text { pal work }\end{array}\end{array}$ & $\begin{array}{l}\text { Relational positioning } \\
\text { - } \quad \text { Employees } \\
\text { Contextual positioning } \\
\text { - Institutionalized dis- } \\
\text { course of well-being at } \\
\text { work } \\
\text { Institutionalized dis- } \\
\text { course of high perfor- } \\
\text { mance }\end{array}$ \\
\hline
\end{tabular}

\subsection{Key contributions}

As a whole, the thesis contributes to enhancing our understanding of the construction of HR practitioner positions in a municipal context. The theoretical contributions of this thesis are made to two literatures: the literature on HR roles and the literature on professional positioning.

\subsubsection{Contributions to the literature on HR roles}

The thesis contributes to the literature on HR practitioner roles in three ways. First, I provide an example of the importance of the institutional context as an opportunity for the construction of HR practitioner roles. Second, I highlight the relational aspect of HR practitioner positioning, and finally, I deepen the discussion of HR interest in well-being at work. 
This thesis concurs with other studies which urge a stronger emphasis on the importance of context in understanding how and why different HR roles evolve (Ferrary 2008; Guerci \& Shani 2013; Lewis et al. 2019; Paauwe 2009; Pritchard \& Symon 2011). Also, I join previous studies which argue that due to their ambiguous position, HR practitioners are very open to influences from outside and adapt to changing circumstances when aiming to secure an important role for themselves (Roche \& Teague 2012; Wright 2008). In other words, HR practitioners are skilful in constantly redefining themselves to improve their position (Caldwell 2003, Sheehan et al. 2014). They are described as clever meaning makers who know how to portray their work as 'legitimate, desirable, rational, and inevitable' (Sheehan et al. 2014, 116). Through the framework of professional positioning, I show how the municipal context and the institutional discourses of high performance and well-being at work are reflected and used skilfully by HR practitioners themselves. Despite challenging the profession by forming new demands, the discourses also provide opportunities for their professional positioning.

As another contribution, I highlight the relational aspect of the professional positioning of HR practitioners, that is, how HR practitioners refer to other actors in the process of positioning themselves. This thesis extends the scope of relevant HR practitioner relations to local policymakers and local residents. The attention that HR studies have given to HR practitioner relationships with policymakers in the public sector is still at the level of identifying them as relevant stakeholders (Knies et al 2018). Moreover, the relationship between local communities, residents and HR practitioners has attracted even less attention (Cleveland et al. 2015).

Through the studies of this thesis, I show how the main strategy of relational positioning is to emphasize the utilitarian aspect of HR practitioners' work. In the context of increasing municipal privatization, from which HR professionals are not exempt, talk of high performance through well-being at work can be interpreted as a strategy to create management expertise in the area. In the same vein, well-being is portrayed as a utility for management to ensure the high performance of the municipality.

As a third contribution, this thesis joins in and elaborates on the discussion on the interest of HR practitioners in well-being at work (Arrowsmith \& Parker 2013; Harris 2007; Keegan \& Francis 2010; Kochan 2004; Renwick 2003; Watson 2007; Woodall \& Winstanley 2001). Through the second study, which identifies the indirect role of well-being at work in HRM performance (Lindström \& Vanhala 2013), I enrich the portrait of HR practitioners in the public sector. This study shows how well-being is portrayed as a bridge to performance, not a result in itself. My third study (Lindström 2016), with its specific focus on how HR practitioners relate to the discourse of well-being at work, takes this finding to a deeper level. I show how HR practitioners embrace well-being at work and construct their position as managers thereof in numerous ways. In the end, wellbeing at work is deployed as a building block in the position of HR practitioners. 
The concept of organizational professionalism (Evetts 2006; Reed 1996) is useful in understanding how HR practitioners are able to combine the institutional discourses of well-being at work with performance as building blocks of their own position. We know from other studies that organizational professionals can combine and adapt organizational priorities, occupational norms and other institutional demands to possible challenges and opportunities which emerge in organizations (Adler et al. 2008; Faulconbridge \& Muzio 2008; Reed 1996). It is their ambiguous status that enables them to creatively shift and combine identifications from demands which at first appear as opposites. Consequently, the ambiguous position of HR practitioners is not the liability it is so often presented to be. In fact, ambiguity is an asset; it enables HR practitioners to adhere to different discourses simultaneously.

\subsubsection{Contributions to the literature on professional positioning}

My thesis contributes to the literature on professional positioning in two ways. First, I answer the calls for richer contextual understanding in studies of professional positioning. Second, I suggest new insight on the literature by combining the framework of discursive legitimation with the analysis of professional positioning.

Regarding richer contextual understanding, this thesis answers the calls for studying professional positioning in a setting where multiple discourses can be identified (Kuhn 2009; Mumby 2005). By so doing, I can provide a rich, 'contextualized construction of subject positions' (Kuhn 2009, 696). Prior to the studies of this thesis, the positions of HR practitioners have not been the focus of research in specific settings where multiple discourses are explicitly identified.

In the first study (Lindström \& Vanhala 2011), we show how HR practitioners employ discursive resources ranging from traditional public sector ideals and demands which can be traced back to the institutionalized discourse of high performance. Traditional public sector ideals of hierarchy and continuity are drawn upon especially when they position themselves vis á vis the city council and when they talk about their dependence on top management. With its connotations of proactivity, control and strategic partnerships, the discourse of performance comes into play when they position themselves towards line managers and top management. The positions are at times conflicting and emerge in different situations; this shows that positioning is a constantly evolving process. Also, in the third study (Lindström 2016), HR practitioners are able to couple the discourse of well-being at work with their municipal environment by drawing upon traditional municipal norms of specialization and formalization.

In the second study (Lindström \& Vanhala 2013), we focus on how HR practitioners discursively construct the performance discourse and position themselves in relation to it. Here, HR practitioners are portrayed in a manner which echoes buzzwords of the institutionalized discourse of performance; they emphasize customer service, added value through process development and increased customer orientation. While repeating and reflecting institutionalized demands for performance, they position themselves as carriers of these valued 
and sought-after attributes. Moreover, HR practitioners adapt the discourse of performance by framing it as an opportunity for them as a professional group to 'get back to the roots' of municipal work. To focus on the needs of local residents is what makes their position strategically important.

In the third study (Lindström 2016), I show how HR practitioners intertwine elements from the institutionalized well-being at work and performance discourses. While well-being at work is clearly portrayed as a sought-after element of HR work, the strength of the performance discourse still appears to override it. The instrumental sense of well-being is emphasized at the expense of its inherent value.

The second contribution I make to the literature on professional positioning is to adapt the framework of discursive legitimation to the analysis of professional positioning. This is accomplished in the third study (Lindström 2016), where I suggest that positioning can be perceived as a discursive process which combines legitimation strategies from the field of practice legitimation (Van Leeuwen 2008) and professional role legitimation (Goodrick \& Reay 2010). HR practitioners legitimate their position by bringing forth themes of well-being at work through a combination of discursive strategies. As a specific contribution to the study of professional positioning, I provide an example of how these strategies are intertwined. To my knowledge, discursive legitimation has so far not been applied as a research framework to any aspect of HR practitioner work.

Furthermore, there are social and political consequences for how HR practitioners position themselves. Studies on well-being, wellness and health promotion (Cederström \& Spicer 2015; Farrell \& Geist-Martin 2005; Holmqvist \& Maravelias 2011) argue that the increasing focus on wellness at work is in fact a current form of social control. Practices which promote physical activity, mental calm or other employee behaviours can be seen to aim at congruence with organizational norms. These norms spill over from health and well-being to responsibility, self-monitoring, creativity and accountability. Consequently, this control is typically internalized by employees themselves; it makes them selfmanagers and eventually accountable for their success or failure in the quest for well-being (Cederström \& Spicer 2015; Holmqvist \& Maravelias 2011). Accordingly, this thesis provides insight into how HR practitioners as actors contribute to this 'wellness syndrome'. In light of the results, HR practitioners position themselves as active promoters of well-being, making their positioning part of the social control directed at employees.

\subsection{Practical implications}

I have organized the practical implications into two sections depending on who I am addressing. First, I discuss the implications of the thesis for HR practitioners in municipalities and other organizations. Second, I offer insights for funders and policymakers involved in the research and development of working life in the public sector. 


\subsubsection{HR practitioner implications}

My thesis hopefully provides material for professional self-reflection by HR practitioners. The results can be useful, for example, in initiating discussions about professional status and improvement amidst global, national and local socio-political and financial developments. Questions which this thesis brings up and which I urge you to discuss with your colleagues and supervisors include the following:

- What opportunities and threats do you identify for your professional position and its development? Start with a wide perspective: Think about society in general with its social, environmental, technological, financial and political developments. Then move on to your work environment, organizational developments and your relations with closer and more distant colleagues.

- What are the values you as a professional want to promote and why? As HR practitioners you are involved in contributing to organizational priorities and incorporating institutional demands. Do they differ or concur with your professional goals?

- How can you promote your professional goals? Do you identify everyday encounters or practices in your life that you are able to affect? Do you have a professional community which backs you up and shares your interests?

The results send a message to HR practitioners that they have strategies to adapt and alter their professional positions in organizations. Institutional discourses and emerging trends provide this opportunity.

Moreover, the results have pointed out tensions and contradictions in the work of HR practitioners. Sweeping tensions under the carpet or bypassing them with a shrug can have detrimental effects for not only individual well-being at work but also the legitimacy of the profession. Paradoxical tensions are everywhere, and they can never be eliminated. I therefore urge HR practitioners to take another approach, and actively seek and discuss tensions. Tensions are not a sign of failure. Instead, the potential in managing paradox is something that can advance the profession, management, leadership, and working life in the Finnish public sector in general.

\subsubsection{Policy implications}

For policymakers involved in the funding and planning of research and development of working life, this thesis provides food for thought on the implications of your decisions. As it points out, your decisions have contributed to institutionalization of the high performance and well-being at work discourses in Finnish society.

This thesis shows how one professional group, HR practitioners in Finnish municipalities, have embraced and applied these discourses in self-definition of 
their obligations, opportunities and work content. By focusing on the experiences of HR practitioners in municipalities, it offers an empirically grounded understanding of how institutionalized working life objectives, communicated through discourse, are incorporated into the work of municipal HR practitioners. Through the work of HR practitioners, these objectives devolve into the work of municipal employees, and hence into the lives of municipal residents.

Moreover, the results are meaningful for policymakers, since they provide information about the strategies that professionals use to adopt and adapt politically desirable objectives for the development of working life. By adopting and adapting objectives as part of their own professional position, the objectives become alive, meaningful and motivating.

\subsection{Limitations of the study}

This thesis has its limitations. There are at least two aspects which are important to keep in mind when interpreting the results and conclusions. The first aspect concerns the research design while the second relates to the geographical and social context.

First, while the thesis has focused on the self-positioning of HR practitioners; other actors have not been heard. Future research should widen the study of professional positions and positioning in another direction and study how other actors outside the HR profession position HR practitioners. What are the rights, duties and tasks of HR practitioners constructed by, for example, employees of municipal organizations, financial directors or policymakers? Also, how might the process of professional positioning differ when the focus is on positioning the other instead of oneself? While HR practitioners employ relational and contextual positioning strategies when positioning themselves, what are the strategies for positioning others?

Second, this study is conducted in a Finnish context, and is therefore characterized by Finnish norms and peculiarities developed over time. In Finland, the role of labour-market organizations is relatively strong; this has contributed to the rather balanced way the institutionalized discourses of performance and well-being at work have developed in the working environment of Finnish municipal HR practitioners. Since countries have very different labour-market traditions, other geographical and social contexts will surely offer other settings for studies on HR practitioners embedded in institutional environments.

\subsection{Suggestions for further research}

Before ending this introductory essay, I draw your attention to possible avenues to advance the field of study.

Finnish local and regional government has not stood still since the data for this thesis was collected. Municipal mergers have continued and the distribution of tasks between local, regional and national government continues to evolve, especially in social and health care. Neither has the work and position of public sector HR practitioners remained unchanged. There is need to study 
how, during the 2010s, the structural turmoil in the organization of public services has imposed demands and provided opportunities for the work of various public sector professionals, HR practitioners included. The ongoing local and regional turmoil provides a wonderful opportunity for scholars to better understand professional positioning in processes of structural change.

This thesis concurs with the conclusions of Wright (2008) and Roche and Teague (2012) that HR practitioners as a professional group are very open to influences and skilful in adapting to changing circumstances in society. While it focused on municipal HR practitioners in the context of the institutionalized discourses of performance and well-being at work, further work is needed on how HR practitioners adapt their professional position to other changes in institutional and organizational working life demands. This work needs to continue because by following and scrutinizing the evolvement of the HR profession combined with the development of the profession's institutional environment, the sometimes diffuse and macro-level changes in working life as well as management fads become more tangible and easier to grasp. Further, by continuing to study HR practitioners and their work in close connection to their institutional environment, we can make sure that research does not develop in a vacuum but stays in contact with its socio-political, financial, environmental and technological context.

At the moment, especially one societal development merits more investigation regarding how HR practitioners position themselves in relation to it. In Finnish society as well as internationally, we can observe signs of an institutionalizing discourse of sustainability, especially since the publication of the latest International Panel of Climate Change (IPCC) report on the impacts of global warming in autumn 2018. In HR research, links between sustainability and HRM are increasingly investigated (Ehnert 2009; Järlström et al. 2018). However, what does the sustainability discourse bring about for HR practitioners? How are they addressing the opportunities and threats this discourse poses them and positioning themselves in relation to it? And how is their relational positioning altered when it comes to the development of sustainability or Corporate Social Responsibility (CSR) managers as a new kind of organizational professional?

One possible avenue in pursuing better understanding of the professional positions of HR practitioners facing different and sometimes conflictual demands is offered by paradox theory. Paradox theory explores how organizations or different groups in organizations can attend to competing demands simultaneously (Lewis 2014; Schad et al. 2016; Smith \& Lewis 2011). Paradox can be understood as a set of two or more poles that represent tensions, opposites or contradictions. However, these tensions are not automatically considered problems to be avoided or even solved. Instead, the paradox approach sees paradoxes as everyday features in all kinds of organizations. In fact, embracing paradox might be the crucial step to making organizations thrive (Lewis 2014; Smith \& Lewis 2011). Currently, there is modest but growing interest in employing the paradox lens in HRM studies (Aust et al. 2015; 2017; Ehnert 2009; Keegan et al. 2018; Kozica \& Brandl 2015). A paradox perspective focuses on the plurality of HRM 
and sees tensions as possible gateways to creative solutions for organizing people at work. However, the positions of HR practitioners have so far not been studied through this framework, and I suggest that further studies applying the paradox theory framework might offer new insights.

For studies similar to this one, I urge the use of different and complementary methodological choices. While I have employed qualitative interviews as data in understanding professional positioning, I suggest that future studies will also employ other materials and complement the findings of this thesis. For example, observation data from meetings and informal discussions between HR practitioners and other occupational groups could capture the enactment of these professional positions in practice, thus enriching or challenging them. 



\section{References}

Academy of Finland (2014). Research programme on the future of work and well-being. Retrieved November 6, 2018, from https://www.aka.fi/en/research-and-sciencepolicy/academy-programmes/completed-programmes/research-programme-onthe-future-of-work-and-well-being/

Ackroyd, S. \& Thompson, P. (1999). Organizational misbehaviour. London: Sage.

Adler, P., Kwon, S. \& Hecksher, C. (2008). Professional work: The emergence of collaborative community. Organization Science, 19(2), 359-376.

Alfes, K., Truss, C. \& Gill, J. (2010). The HR manager as change agent: Evidence from the public sector. Journal of Change Management, 10(1), 109-127.

Alvesson, M. (2003). Beyond neopositivists, romantics, and localists: A reflexive approach to interviews in organizational research. Academy of Management Review, 28(1), 13-33.

Alvesson, M. \& Deetz, S. (2000). Doing critical management research. London: Sage.

Alvesson, M. \& Kärreman, D. (2000). Varieties of discourse: On the study of organizations through discourse analysis. Human Relations, 53(9), 1125-1149.

Anttonen, H. \& Räsänen, T. (Eds.). (2008). Well-being at work: New innovations and good practices. Helsinki: Finnish Institute of Occupational Health.

Arrowsmith, J. \& Parker, J. (2013). The meaning of 'employee engagement' for the values and roles of the HRM function. International Journal of Human Resource Management, 24(14), 2692-2712.

Ashforth, B. (2001). Role transitions in organizational life: An identity-based perspective. Mahwah: Erlbaum.

Association of Finnish Local and Regional Authorities (2019). Finnish municipalities and regions. Retrieved March 29, 2019 from www.localfinland.fi/expert-services/finnish-municipalities-and-regions

Association of Finnish Local and Regional Authorities (2016). Local Finland. Retrieved January 31, 2016, from http://www.localfinland.fi/en/authorities/Pages/default.aspx

Association of Finnish Local and Regional Authorities (2010). Kuntatyö. Retrieved September 27, 2010, from http://www.kunnat.net/k perussivu.asp?path $=1 ; 55264 ; 122868 ; 75935$

Association of Finnish Local and Regional Authorities (2009). Kuntapalvelujen pelastusohjelma. Helsinki: Association of Finnish Local and Regional Authorities.

Association of Finnish Local and Regional Authorities (2008). Kuntatuottavuuden $A B C$. Helsinki: Association of Finnish Local and Regional Authorities.

Auer, J. \& Teerimäki, N. (1982). Puoli vuosisataa Imatran voimaa. Imatran voima Oy:n synty ja kehitys 1980-luvulle. Helsinki: Imatran Voima.

Aust, I., Brandl, J. \& Keegan, A. (2015). State-of-the-art and future directions for HRM from a paradox perspective: Introduction to the special issue. German Journal of Research in Human Resource Management, 29(3-4), 194-213.

Aust, I., Brandl, J., Keegan, A. \& Lensges, M. (2017). Tensions in managing human resources: Introducing a paradox framework and research agenda. In W. Smith, M. Lewis, P. Jarzabkowski \& A. Langley (Eds.), The Oxford handbook of organizational paradox (pp. 413-433). Oxford: Oxford University Press. 
Bach, S. \& Bordogna, L. (2013). Reframing public service employment relations: The impact of economic crisis and the new EU economic governance. European Journal of Industrial Relations, 19(4), 279-294.

Bach, S. \& Bordogna, L. (2011). Varieties of New Public Management or alternative models? The reform of public service employment relations in industrialized democracies. International Journal of Human Resource Management, 22(11), 2281-2294.

Bach, S. \& Kessler, I. (2007). HRM and the New Public Management. In P. Boxall, J. Purcell \& P. Wright (Eds.), The Oxford handbook of human resource management (pp. 469-488). Oxford: Oxford University Press.

Baert, P., Weinberg, D. \& Mottier, V. (2014). Social constructionism, postmodernism and deconstructionism. In I. C. Jarvie, \& J. Zamora-Bonilla (Eds.), The Sage handbook of the philosophy of social sciences (pp. 475-486). London: Sage.

Barley, S. \& Kunda, G. (1992). Design and devotion: Surges of rational and normative ideologies of control in managerial discourse. Administrative Science Quarterly, 37(3), 363-399.

Berger, P. \& Luckmann, T. (1967). The social construction of reality. London: Penguin.

Blom, R. \& Hautaniemi, A. (2009). Johdanto. In R. Blom, \& A. Hautaniemi (Eds.), Työelämä muиttuu, joustaako hyvinvointi? (pp. 7-19). Helsinki: Gaudeamus.

Boselie, P., Dietz, G. \& Boon, C. (2005). Commonalities and contradictions in HRM and performance research. Human Resource Management Journal, 15(3), 67-94.

Brivot, M. (2011). Controls of knowledge production, sharing and use in bureaucratized professional service firms. Organization Studies, 32(4), 489-508.

Brown, A. \& Lewis, M. (2011). Identities, discipline and routines. Organization Studies, 32(7), 871-895.

Brown, K. (2004). Human Resource Management in the public sector. Public Management Review, 6(3), 303-309.

Burns, J. \& Baldvinsdottir, G. (2005). An institutional perspective of accountants' new roles - the interplay of contradictions and praxis. European Accounting Review, 14(4), 725-757.

Burr, V. (2003). Social constructionism. Second edition. London: Routledge.

Caldwell, R. (2003). The changing roles of personnel managers: Old ambiguities, new uncertainties. Journal of Management Studies, 40(4), 983-1004.

Carollo, L. \& Guerci, M. (2017). Between continuity and change: CSR managers' occupational rhetorics. Journal of Organizational Change Management, 30(4), 632-646.

Cederström, C. \& Spicer, A. (2015). The wellness syndrome. Cambridge: Polity.

Chouliaraki, L. \& Fairclough, N. (2010). Critical discourse analysis in organizational studies: Towards an integrationist methodology. Journal of Management Studies, 47(6), 1213-1218.

Chreim, S., Williams, B. \& Hinings, C. (2007). Interlevel influences on the reconstruction of professional role identity. Academy of Management Journal, 50(6), 15151539.

Christensen, T. \& Lægreid, P. (2002). New Public Management: Puzzles of democracy and the influence of citizens. Journal of Political Philosophy, 10(3), 267-295.

Cleveland, J., Byrne, S. \& Cavanagh, T. (2015). The future of HR is RH: Respect for humanity at work. Human Resource Management Review, 25(2), 146-161.

Colley, L., McCourt, W. \& Waterhouse, J. (2012). Hybrids and contradictions: Human Resource Management in the contemporary public sector. International Journal of Public Administration, 35(8), 507-512. 
Collinson, D. (2003). Identities and insecurities: Selves at work. Organization, 10(3), 527-547.

Daudigeos, T. (2013). In their profession's service: How staff professionals exert influence in their organization. Journal of Management Studies, 50(5), 722-749.

Dick, P. (2004). Discourse analysis. In C. Cassell, \& G. Symon (Eds.), Essential guide to qualitative methods in organizational research (pp. 203-213). London: Sage.

Dodge, R., Daily, A., Huyton, J. \& Sanders, I. (2012). The challenge of defining wellbeing. International Journal of Well-being, 2(3), 222-234.

DuGay, P. (1993). Entrepreneurial management in the public sector. Work, Employment and Society, 7(4), 643-648.

Ehnert, I. (2009). Sustainable human resource management. A conceptual and exploratory analysis from a paradox perspective. Heidelberg: Springer.

Etzioni, A. (1969). The semi-professions and their organization: Teachers, nurses, social workers. New York: Free Press.

Eurofound. (2015). Collective bargaining in Europe in the 21st century. Luxembourg: Publications Office of the European Union.

Evetts, J. (2011). A new professionalism? Challenges and opportunities. Current Sociology, 59, 406-422.

Evetts, J. (2006). Introduction: Trust and professionalism: Challenges and occupational changes. Current Sociology, 54(4), 515-531.

Fairclough, N. (2005). Discourse analysis in organization studies: The case for critical realism. Organization Studies, 26(6), 915-939.

Fairclough, N. (2003). Analysing discourse: Textual analysis for social research. London: Routledge.

Fairclough, N. (1995). Critical discourse analysis: The critical study of language. London: Longman.

Fairclough, N. (1992). Discourse and social change. Cambridge: Polity Press.

Farndale, E. \& Hope-Hailey, V. (2009). Personnel departmental power: Realities from the UK higher education sector. Management Revue, 20(4), 392-412.

Farrell, A. \& Geist-Martin, P. (2005). Communicating social health: Perceptions of wellness at work. Management Communication Quarterly, 18(4), 543-592.

Faulconbridge, J. \& Muzio, D. (2008). Organizational professionalism in globalizing law firms. Work, Employment and Society, 22(1), 7-25.

Ferrary, M. (2008). A stakeholder's perspective on Human Resource Management. Journal of Business Ethics, 87(1), 31-43.

Findlay, P., Arne, L. \& Warhurst, C. (2013). The challenge of job quality. Human Relations, 66(4), 441-451.

Finnish Institute of Occupational Health. (2019). Työhyvinvointi. Retrieved September 8, 2019, from https://www.ttl.fi/tyoyhteiso/tyohyvinvointi/

Francis, H. \& Keegan, A. (2006). The changing face of HRM: In search of balance. Human Resource Management Journal, 16(3), 231-249.

Freidson, E. (2001). Professionalism: The third logic. Cambridge: Polity.

Freidson, E. (1970). Profession of medicine: A study of the sociology of applied knowledge. New York: Dodd, Mead \& Co.

Goodrick, E. \& Reay, T. (2010). Florence nightingale endures: Legitimizing a new professional role identity. Journal of Management Studies, 47, 55-84.

Gould-Williams. J. (2007). HR practices, organizational climate and employee outcomes: Evaluating social exchange relationships in local government. International Journal of Human Resource Management, 18(1), 1627-1647. 
Grant, D., Iedema, R. \& Oswick, C. (2009). Discourse and Critical Management Studies. In M. Alvesson, T. Bridgman \& H. Willmott (Eds.), The Oxford handbook of critical management studies (pp. 213-231). Oxford: Oxford University Press.

Greenwood, E. (1957). Attributes of a profession. Social Work, 2, 45-55.

Gubbins, C. \& Garavan, T. (2016). Social capital effects on the career and development outcomes of HR professionals. Human Resource Management, 55(3), 241-260.

Guerci, M. \& Shani, A. (2013). Moving toward stakeholder-based HRM: A perspective of italian HR managers. International Journal of Human Resource Management, 24(6), 1130-1150.

Guest, D. (1987). Human Resource Management and industrial relations. Journal of Management Studies, 24(5), 503-521.

Hakanen, J., Hakonen, A., Seppälä, P. \& Viitala, R. (2019). Uudistu ja onnistu hyvällä henkilöstöjohtamisella. ARTTU2-ohjelman tutkimuksia nro 7. Helsinki: Association of Finnish Local and Regional Authorities.

Hall, S. (1996). Who needs identity? In S. Hall, \& P. DuGay (Eds.), Questions of cultural identity (pp. 1-17). Thousand Oaks: Sage.

Harré, R. \& van Langenhove, L. (1999). The dynamics of social episodes. In R. Harré, \& L. van Langenhove (Eds.), Positioning theory: Moral contexts of intentional action (pp. 1-12). Malden: Blackwell.

Harris, L. (2005). UK public sector reform and the 'performance agenda' in UK local government: HRM challenges and dilemmas. Personnel Review, 34(6), 681-696.

Harris, L. (2007). The changing nature of the HR function in UK local government and its role as 'employee champion'. Employee Relations, 30(1), 34-47.

Haveri, A. (2006). Complexity in local government change. Public Management Review, 8(1), 31-46.

Hesketh, A. \& Fleetwood, S. (2006). Beyond measuring the human resources management - organizational performance link: Applying critical realist meta-theory. Organization, 13(5), 677-699.

Holmqvist, M. \& Maravelias, C. (2011). Managing healthy organizations. worksite health promotion and the new self-management paradigm. London: Routledge.

Hope-Hailey, V., Farndale, E. \& Truss, C. (2005). The HR department's role in organisational performance. Human Resource Management Journal, 15(3), 49-66.

Huselid, M. (1995). The impact of Human Resource Management practices on turnover, productivity, and corporate financial performance. Academy of Management Journal, 38(3), 635-672.

Häikiö, L. (2010). The diversity of citizenship and democracy in local public management reform. Public Management Review, 12(3), 363-384.

Jacoby, S. (2004). Employing bureaucracy. Managers, unions and the transformation of work in the 20th century. New Jersey: Lawrence Erlbaum Associates.

Janssens, M. \& Steyaert, C. (2009). HRM and performance: A plea for reflexivity in HRM studies. Journal of Management Studies, 46(1), 143-155.

Johnson, P. \& Duberley, J. (2009). Introduction - the importance of epistemology in management research. In P. Johnson, \& J. Duberley (Eds.), Understanding management research. An introduction to epistemology (pp. 1-10). London: Sage.

Jolanki, O. \& Karhunen, S. (2010). Renki vai isäntä? Analyysiohjelmat laadullisessa tutkimuksessa. In J. Ruusuvuori, P. Nikander \& M. Hyvärinen (Eds.), Haastattelun analyysi (pp. 395-410). Tampere: Vastapaino.

Järlström, M., Saru, E. \& Vanhala, S. (2018). Sustainable Human Resource Management with salience of stakeholders: A top management perspective. Journal of Business Ethics, 152(3), 703-724. 
Kangasharju, A. \& Pääkkönen, J. (2010). Mainettaan parempi tuottavuusohjelma? Katsaus valtion virastojen ja laitosten työn tuottavuuteen ja työhyvinvointiin. Helsinki: Government Institute for Economic Research.

Keegan, A., Bitterling, I., Sylva, H. \& Hoeksema, L. (2018). Organizing the HRM function: Responses to paradoxes, variety and dynamism. Human Resource Management, 57(5), 1111-1126.

Keegan, A. \& Francis, H. (2010). Practitioner talk: The changing textscape of HRM and emergence of HR business partnership. International Journal of Human Resource Management, 21(6), 873-898.

Kettunen, P. (2006). New forms of service production - Fashion or necessity? Kunnallistieteellinen aikakauskirja, 34(4), 330-339.

Kivistö, S., Turtiainen, J. \& Väänänen, A. (2014). Suojelusta työhyvinvointiin: Työntekijyyden ja työympäristön rajojen muutos työturvallisuuden lainvalmistelussa. In A. Väänänen, \& J. Turtiainen (Eds.), Suomalainen työntekijyys 1945-2013 (pp. 189-226). Tampere: Vastapaino.

Knies, E., Boselie, P., Gould-Williams, J. \& Vandenabeele, W. (2018). Strategic human resource management and public sector performance: Context matters. The International Journal of Human Resource Management, 26(3) , 1-13.

Knights, D. \& Willmott, H. (1989). Power and subjectivity at work. Sociology, 23, 535558.

Kochan, T. (2004). Restoring trust in the human resource management profession. Asia Pacific Journal of Human Resources, 42(2), 132-146.

Kozica, A. \& Brandl, J. (2015). Handling paradoxical tensions through conventions: The case of performance appraisal. Zeitschrift Für Personalforschung, 29(1), 4968.

Kuhn, T. (2009). Positioning lawyers: Discursive resources, professional ethics and identification. Organization, 16(5), 681-704.

Kuhn, T. (1962). The structure of scientific revolutions. Chicago: University of Chicago Press.

Kuokkanen, A., Laakso, A. \& Seeck, H. (2010). Management paradigms in personnel magazines of the finnish metal and forest industries. Journal of Management History, 16(2), 195-215.

Kuokkanen, A. \& Seeck, H. (2007). Ihmissuhdekoulukunta - synty, sisältö ja perintö. Työelämän Tutkimus, 5(2), 118-137.

LaPointe, K. \& Tienari, J. (2015). Henkilöstötyön naisistuminen. In J. Kauhanen, S. Leppävuori, L. Malin \& S. Mansukoski (Eds.), Henkilöstöjohtaminen Suomessa 1960-2015. Ihmisistä on kysymys (pp. 170-182). Helsinki: Aalto University.

Larson, M. (1977). The rise of professionalism: A sociological analysis. Berkeley: University of California Press.

Lawrence, T. \& Suddaby, R. (2006). Institutions and institutional work. In S. Clegg, C. Hardy, T. Lawrence \& W. Nord (Eds.), Handbook of organization studies (pp. 214-254). London: Sage.

Legge, K. (2005). Human resource management: Rhetorics and realities. Anniversary edition. London: Palgrave MacMillan.

Legge, K. (1978). Power, innovation and problem-solving in personnel management. London: McGraw-Hill.

Leppävuori, S. (2015). Yhteisöstä voimaa ammattilaisille - Henry ja sen edeltäjät. In J. Kauhanen, S. Leppävuori, L. Malin \& S. Mansukoski (Eds.), Henkilöstöjohtaminen Suomessa 1960-2015. Ihmisistä on kysymys (pp. 183-192). Helsinki: Aalto University. 
Lewis, A., Cardy, R. \& Huang, L. (2019). Institutional theory and HRM: A new look. Human Resource Management Review, 29(3), 316-335.

Lewis, M., Andriopoulos, C. \& Smith, W. (2014). Paradoxical leadership to enable strategic agility. California Management Review, 56(3), 58-77.

Lilja, K. (1987). Henkilöstöhallinnon ammattikäytännön kehityspiirteitä Suomessa. Hallinnon Tutkimus, (6)3, 185-194.

Lindström, K., Björklund, C., Mykletun, R., Furunes, T., Gard, G. \& Pahkin, K. (2008). Nordic questionnaire for monitoring the age diverse workforce. Copenhagen: Nordic Council of Ministers.

Lindström, S. (2016). 'An army of our own'. Legitimating the professional position of HR through well-being at work. Scandinavian Journal of Management, 32(4), 189-196.

Lindström, S. \& Vanhala, S. (2013). Performance in local government HRM: The role of external customers. Baltic Journal of Management, 8(3), 252-268.

Lindström, S. \& Vanhala, S. (2011). Divergence in HR functional roles in local government. Public Management Review, 13(7), 1023-1040.

Local Government Employers (2018). Henkilöstötilastot. Retrieved July 30, 2018, from https://www.kt.fi/tilastot-ja-julkaisut/henkilostotilastot

Local Government Employers (2008). Tuloksellisen toiminnan kehittämistä koskeva suositus (17.12.2008). Helsinki: Local Government Employers.

Local Government Employers (2007a). Kuntapalvelujen strateginen toteuttaminen henkilöstöjohtamisen avulla (suositus 14.3.2007). Helsinki: Local Government Employers.

Local Government Employers (2007b). Työhyvinvoinnin toimintalinjat ja hyvät käytännöt (suositus kunta-alalle 30.5.2007). Helsinki: Local Government Employers.

Local Government Employers (2003). Hyvä henkilöstöjohtaminen kuntasi menestystekijä. Työssä jaksamisen ohjelma. Helsinki: Local Government Employers.

Luoma, M. \& Viitala, R. (2015). Suomalainen henkilöstöjohtaminen kirjallisuuden valossa. Omaa, lainattua vai yhdisteltyä? In J. Kauhanen, S. Leppävuori, L. Malin \& S. Mansukoski (Eds.), Henkilöstöjohtaminen Suomessa 1960-2015. Ihmisistä on kysymys (pp. 15-41). Helsinki: Aalto University.

Maguire, S. \& Hardy, C. (2009). Discourse and deinstitutionalization: The decline of DDT. Academy of Management Journal, 52(1), 148-178.

Mamia, T. (2009). Mistä työhyvinvointi syntyy? In R. Blom, \& A. Hautaniemi (Eds.), Työelämä muиttuu, joustaako hyvinvointi? (pp. 20-55). Helsinki: Gaudeamus.

Martel, J. \& Dupuis, G. (2006). Quality of work life: Theoretical and methodological problems, and presentation of a new model and measuring instrument. Social Indicators Research, 77(2), 333-368.

Ministry of Economic Affairs and Employment (2017). Working life barometer. Autumn 2016. TEM reports 34/2017. Helsinki: Ministry of economic affairs and employment.

Ministry of Employment and the Economy (2012). Laadukkaasti tulosta. Miten hyvä työelämän laatu liittyy työyhteisön menestykseen ja hyvään taloudelliseen tulokseen? Helsinki: Ministry of employment and the economy.

Ministry of Employment and the Economy (1994). Työympäristötutkimus Suomessa ja sen painoalueet. Työpoliittinen tutkimus 69. Helsinki: Ministry of employment.

Ministry of Social Affairs and Health (2005). Työhyvinvointitutkimus Suomessa ja sen painoalueet terveyden ja turvallisuuden näkökulmasta. Selvityksiä 2005:25. Helsinki: Ministry of social affairs and health.

Ministry of Social Affairs and Health (1998). Työympäristötutkimus Suomessa ja sen painoalueet. Helsinki: Ministry of social affairs and health. 
Morgan, P. \& Allington, N. (2002). Has the public sector retained its 'model employer status'? Public Money \& Management, 22(1), 35-42.

Morley, M., Gunnigle, P., O'Sullivan, M. \& Collings, D. (2006). New directions in the roles and responsibilities of the HRM function. Personnel Review, 35(6), 609617.

Mumby, D. (2005). Theorizing resistance in organization studies: A dialectical approach. Management Communication Quarterly, 19(1), 19-44.

Paauwe, J. (2009). HRM and performance: Achievements, methodological issues and prospects. Journal of Management Studies, 46(1), 129-142.

Phillips, N. \& Hardy, C. (1997). Managing multiple identities: Discourse, legitimacy and resources in the UK refugee system. Organization, 4(2), 159-185.

Pietikäinen, P. (Ed.). (2011). Työstä, jousta ja jaksa. Työn ja hyvinvoinnin tulevaisuus. Helsinki: Gaudeamus.

Pohler, D. \& Willness, C. (2014). Balancing interests in the search for occupational legitimacy: The HR professionalization project in Canada. Human Resource Management, 53(3), 467-488.

Pollitt, C. \& Bouckaert, G. (2004). Public management reform: A comparative analysis. (Second Edition). Oxford: Oxford University Press.

Pritchard, K. \& Symon, G. (2011). Identity on the line: Constructing professional identity in a HR call centre. Work, Employment \& Society, 25(3), 434-450.

Productivity Round Table (2011). Tulevaisuus tehdään työpaikoilla. Toimialoilta vauhtia tuottavuuden ja työelämän laadun kehittämiseen. Retrieved November 11, 2018, from https://docplayer.fi/1622898-Tulevaisuus-tehdaan-tyopaikoilla-toimialoilta-vauhtia-tuottavuuden-ja-tyoelaman-laadun-kehittamiseen.html

Rao, H., Monin, P. \& Durand, R. (2003). Institutional change in toque ville: Nouvelle cuisine as an identity movement in french gastronomy. American Journal of Sociology, 108(4), 795-843.

Reed, M. (2009). Critical realism in critical management studies. In M. Alvesson, T. Bridgman \& H. Willmott (Eds.), The Oxford handbook of critical management studies (pp. 52-75). Oxford: Oxford University Press.

Reed, M. (2004). Getting real about organizational discourse. In D. Grant, C. Hardy, C. Oswick \& L. Putnam (Eds.), The Sage handbook of organizational discourse (pp. 413-420). London: Sage.

Reed, M. (1996). Expert power and control in late modernity: An empirical review and theoretical synthesis. Organisation Studies, 17(4), 573-597.

Renwick, D. (2003). HR managers: Guardians of employee wellbeing? Personnel Review, 32(3), 341-359.

Roche, W. \& Teague, P. (2012). Business partners and working the pumps: Human resource managers in the recession. Human Relations, 65(10), 1333-1358.

Schad, J., Lewis, M., Raisch, S. \& Smith, W. (2016). Paradox research in management science: Looking back to move forward. Academy of Management Annals, 10(1), $1-60$.

Searle, J. (1995). The social construction of reality. New York: Free Press.

Sheehan, C., De Cierci, H., Greenwood, M. \& Van Buren, H. (2014). HR professional role tensions: Perceptions and responses of the top management team. Human Resource Management, 53(1), 115-130.

Smith, W. \& Lewis, M. (2011). Toward a theory of paradox: A dynamic equilibrium model of organizing. Academy of Management Review, 36(2), 381-403.

Sointu, E. (2005). The rise of an ideal: Tracing changing discourses of wellbeing. Sociological Review, 53(2), 255-274. 
Stenvall, J., Majoinen, K., Syväjärvi, A., Vakkala, H. \& Selin, A. (2007). 'Take your stuff and go there'. Managing change and human resources in municipal mergers. Acta no. 191. Helsinki: University of Lapland and Association of Finnish Local and Regional Authorities.

Storey, J. (1992). Developments in the management of human resources. Oxford: Blackwell.

Suddaby, R. \& Viale, T. (2011). Professionals and field-level change: Institutional work and the professional project. Current Sociology, 59(4), 423-441.

Thomas, R. \& Davies, A. (2005). Theorizing the micro-politics of resistance: New public management and managerial identities in the UK public services. Organization Studies, 26(5), 683-706.

Tiittula, L. \& Ruusuvuori, J. (2009). Johdanto. In J. Ruusuvuori, \& L. Tiittula (Eds.), Haastattelu. tutkimus, tilanteet ja vuorovaikutus. (pp. 9-21). Tampere: Vastapaino.

Torres, L. (2004). Trajectories in public administration reforms in European continental countries. Australian Journal of Public Administration, 63(3), 99-112.

Truss, C. (2013). The distinctiveness of human resource management in the public sector. In R. Burke, A. Noblet, J. Andrew \& C. Cooper (Eds.), Human resource management in the public sector (pp. 17-36). Cheltenham: Edward Elgar.

Truss, C. (2009). Changing HR functional forms in the UK public sector. International Journal of Human Resource Management, 20(4), 717-737.

Truss, C. (2008). Continuity and change: The role of the HR function in the modern public sector. Public Administration, 86(4), 1071-1088.

Truss, C., Gratton, L., Hope-Hailey, V., Stiles, P. \& Zaleska, J. (2002). Paying the piper: Choice and constraint in changing HR functional roles. Human Resource Management Journal, 12(2), 39-63.

Tuomi, K., Ilmarinen, J., Jahkola, A., Katajarinne, L. \& Tulkki, A. (1998). Work ability index. Second edition. Helsinki: Finnish Institute of Occupational Health.

Tyson, S. \& Fell, A. (1986). Evaluating the personnel function. London: Hutchinson.

Törrönen, J. (2013). Situational, cultural and societal identities. Analysing subject positions as classifications, participant roles, viewpoints and interactive positions. Journal for the Theory of Social Behaviour, 44(1), 80-98.

Törrönen, J. (2001). The concept of subject position in empirical social research. Journal for the Theory of Social Behavior, 31(3), 313-329.

Ulrich, D. (1997). Human resource champions: The next agenda for adding value and delivering results. Boston: Harvard Business School Press.

Ulrich, D. \& Brockbank, W. (2005). The HR value proposition. Boston: Harvard Business School Press.

Vaara, E. \& Tienari, J. (2008). A discursive perspective on legitimation strategies in multinational corporations. Academy of Management Review, 33(4), 985-993.

Van Buren, H., Greenwood, M. \& Sheehan, C. (2011). Strategic human resource management and the decline of employee focus. Human Resource Management Review, 21(3), 209-219.

Van Leeuwen, T. (2008). Discourse and practice: New tools for critical discourse analysis. Oxford: Oxford University Press.

Van Leeuwen, T. \& Wodak, R. (1999). Legitimizing immigration control: A discoursehistorical analysis. Discourse Studies, 1(1), 83-118.

Vanhala, S. (Ed.). (2013). Hyöty - hyvinvointia ja tuloksellisuutta hyvällä henkilöstöjohtamisella. Kauppa ja talous 5/2013. Helsinki: Aalto University.

Vanhala, S. (1995). Human resource management in Finland. Employee Relations, 17(7), 31-56. 
Vanhala, S., Tilev, K. \& Lindström, S. (Eds.). (2012). Ristivetoa vai yhtä köyttä? Henkilöstöjohtaminen, työhyvinvointi ja tuloksellisuus. Kauppa ja talous 2/2012. Helsinki: Aalto University.

Viitala, R. \& Järlström, M. (Eds.). (2014). Henkilöstöjohtaminen uuden edessä. Henkilöstöbarometrin nostamat kehityshaasteet. Vaasa: Vaasa University.

Väänänen, A. \& Varje, P. (2014). Terveenä työssä: Riskit ja työterveys lehdistökeskustelussa. In A. Väänänen, \& J. Turtiainen (Eds.), Suomalainen työntekijyys 1945 2013 (pp. 227-260). Tampere: Vastapaino.

Wainwright, D. \& Calnan, M. (2002). Work stress: The making of a modern epidemic. Buckingham: Open University Press.

Walker, R. \& Boyne, G. (2009). Introduction: Determinants of performance in public organizations. Public Administration, 87(3), 433-439.

Wall, T. \& Wood, S. (2005). The romance of human resource management and business performance, and the case for big science. Human Relations, 58(4), 429-462.

Watson, T. (2007). Organization theory and HRM. In P. Boxall, J. Purcell \& P. Wright (Eds.), The Oxford handbook of human resource management (pp. 108-127). Oxford: Oxford University Press.

Watson, T. (1995). In search of HRM: Beyond the rhetoric and reality distinction or the case of the dog that didn't bark. Personnel Review, 24(4), 6-16.

Willmott, H. (1993). Strength is ignorance - slavery is freedom: Managing culture in modern organizations. Journal of Management Studies, 30(4), 515-552.

Wodak, R. \& Meyer, M. (Eds.). (2009). Methods of critical discourse analysis. Second edition. London: Sage.

Woodall, J. \& Winstanley, D. (2001). The place of ethics in HRM. In J. Storey (Ed.), Human resource management: A critical text (2nd edition), pp. 37-56). London: Thomson learning.

Wright, C. (2009). Inside out? Organizational membership, ambiguity and the ambivalent identity of the internal consultant. British Journal of Management, 20(3), 309-322.

Wright, C. (2008). Reinventing human resource management: Business partners, internal consultants and the limits to professionalization. Human Relations, 61(8), 1063-1086.

Wright, C., Nyberg, D. \& Grant, D. (2012). 'Hippies on the third floor': Climate change, narrative identity and the micro-politics of corporate environmentalism. Organization Studies, 33(11), 1451-1475.

Ybema, S., Keenoy, T., Oswick, C., Beverungen, A., Ellis, N. \& Sabelis, I. (2009). Articulating identities. Human Relations, 62(3), 299-322.

Zanoni, P. \& Janssens, M. (2004). Deconstructing difference: The rhetoric of human resource managers' diversity discourses. Organization Studies, 25(1), 55-74. 
